\title{
Article \\ Reconnecting Farmers with Nature through Agroecological Transitions: Interacting Niches and Experimentation and the Role of Agricultural Knowledge and Innovation Systems
}

\author{
Cynthia Giagnocavo ${ }^{1, *(\mathbb{D})}$, Miguel de Cara-García ${ }^{2}\left(\mathbb{D}\right.$, Mónica González ${ }^{3,4}$, Melchor Juan ${ }^{5}$, \\ José Ignacio Marín-Guirao $^{2}{ }^{(\mathbb{D}}$, Sepide Mehrabi ${ }^{6}{ }^{(D)}$, Estefanía Rodríguez ${ }^{2}$, Jan van der Blom ${ }^{7}$ \\ and Eduardo Crisol-Martínez 7,8,9
}

Citation: Giagnocavo, C.; de Cara-García, M.; González, M.; Juan, M.; Marín-Guirao, J.I.; Mehrabi, S.; Rodríguez, E.; van der Blom, J.; Crisol-Martínez, E. Reconnecting Farmers with Nature through Agroecological Transitions: Interacting Niches and Experimentation and the Role of Agricultural Knowledge and Innovation Systems. Agriculture 2022, 12, 137. https://doi.org/10.3390/ agriculture12020137

Academic Editors: José Luis Vicente-Vicente, Cristina Quintas-Soriano and María D. López-Rodríguez

Received: 15 December 2021 Accepted: 14 January 2022 Published: 20 January 2022 Publisher's Note: MDPI stays neutral with regard to jurisdictional claims in published maps and institutional affiliations.

Copyright: (c) 2022 by the authors. Licensee MDPI, Basel, Switzerland. This article is an open access article distributed under the terms and conditions of the Creative Commons Attribution (CC BY) license (https:// creativecommons.org/licenses/by/ $4.0 /)$.
1 Cátedra COEXPHAL-UAL on Horticulture, Cooperative Studies and Sustainable Development, Department of Economics and Business, University of Almería, Carretera Sacramento s/n, 04120 La Cañada, Almeria, Spain

2 Department of Sustainable Crop Protection, Andalusian Institute of Agricultural and Fisheries Research Training (IFAPA) La Mojonera, Camino San Nicolás, 1, 04745 La Mojonera, Almeria, Spain; franciscom.cara@juntadeandalucia.es (M.d.C.-G.); josei.marin@juntadeandalucia.es (J.I.M.-G.); mestefania.rodriguez@juntadeandalucia.es (E.R.)

3 Experimental Station of Foundation Cajamar, 04710 Las Palmerillas, Almeria, Spain; mgonzalez@agrobio.es 4 Agrobio S.L. Ctra Nacional 340, Km 419, $n^{\circ}$ 81, 04746 La Mojonera, Almeria, Spain

5 Laboratory of Phytopathology, LABCOLOR-COEXPHAL (Laboratory of Association of Vegetable and Fruit Growers of Almeria), C $\backslash$ Esteban Murillo, 3, 04746 La Mojonera, Almeria, Spain; melchor@coexphal.es

6 Department of Economics and Business, University of Almería, Carretera Sacramento s/n, 04120 La Cañada, Almeria, Spain; sepidemehrabi@ual.es

7 Department of Crop Production Techniques, COEXPHAL (Association of Vegetable and Fruit Growers of Almeria), C $\backslash$ Esteban Murillo, 3, 04746 La Mojonera, Almeria, Spain; jvdblom@coexphal.es (J.v.d.B.); ecrisol@coexphal.es (E.C.-M.)

8 Escuela de Agronomía, Facultad de Ciencias Agrarias y Forestales, Universidad Católica del Maule, Casilla 7-D, Curico 3349001, Chile

9 EcoLaVerna Integral Restoration Ecology, Bridestown, Kildinan, T56CD39 Co. Cork, Ireland

* Correspondence: cgiagnocavo@ual.es

Abstract: Sustainability transitions in agriculture are explored through an analysis of niche initiatives within a common production system, relying on sustainable transitions, multi-level perspectives, and agroecological frameworks, and involving multi-actor, agricultural knowledge, and innovation systems (AKIS). The article focuses on how experimental niches and sustainable activities affect farmers' relationships with nature, and the reconceptualisation of the production system in which they operate, particularly where this system is embedded in less sustainable conventional or dominant regimes and landscapes. The need for fundamental changes, in the way that humans interact with nature, is widely argued for in order to achieve sustainable development, and farmers occupy a central role through participation in complex networks of agri-food systems. They have also found themselves disconnected from nature through conventional agri-industrial production practices. Four niches (biological control, ecological restoration, soil health, and ecological pond management) within the greenhouse sector of Almeria (SE Spain) are explored in a case study. Our results indicate that a farmer's interaction with nature is functional, but through agroecological practices, a deeper understanding of the ecosystems in which greenhouse landscapes are embedded may be gained. As they become more connected to nature and benefit from ecosystem services, they can transition to more sustainable agricultural systems.

Keywords: human nature connectedness; sustainability transitions; agricultural innovations; multilevel perspective; agroecology; agricultural knowledge and innovation systems (AKIS); conservative agriculture practices; knowledge co-production; mediterranean horticulture; integrated pest management; greenhouses; soil health; biological control; pond naturalisation; collective action; socio-ecological systems 


\section{Introduction}

In this paper, we explore processes of sustainability transitions in agriculture through the analysis of four niche initiatives in Almeria, South-East Spain, within a common intensive greenhouse production system, involving diverse multi-actor, agricultural knowledge and innovation systems (AKIS). A central focus of our research is to understand how involvement in niche experimental and sustainable activities affects a farmer's relationship with nature, and the reconceptualisation of the production system in which such niches operate, particularly where this system is heavily embedded in less sustainable conventional or dominant regimes and landscapes. The need for fundamental changes in the way that humans interact with nature is widely argued for in order to achieve sustainable development [1] and farmers; both, in their roles as humans and producers within the complex network of agri-food systems, occupy crucial roles. Through agricultural activity, a farmer's interaction with nature is functional and economic. However, through the practice of agriculture, a deeper understanding of the ecosystems in which farming activities are located may be gained by farmers, their organisations, and, in general, their AKIS. As they become more connected to nature through practice, they can transition to more sustainable agricultural systems.

Agricultural activity has a significant social, economic, and environmental impact, particularly in intensive systems. Recent studies based on Crippa et al. [2] and Rockstrom et al. [3], amongst others, demonstrate that dominant agricultural and food systems have led to serious and ongoing resource depletion and severe and inequitable environmental and social impacts. In addition to academic calls for transformation, social and political stakeholders are also calling for change in agri-food systems [4-7]. The United Nations Environment Programme (UNEP) [8] has made it abundantly clear that making the transformation of food and water systems more equitable and resilient is an urgent goal, citing the need to implement a wide range of agricultural management systems and approaches, including conservation agriculture, organic farming, agroecology, integrated pest and nutrient management, soil and water conservation, agroforestry, and irrigation management, to name a few (p. 121), applicable to various farming systems.

More specifically, the UNEP report refers to the need for a reduction in nitrogen and phosphorus imbalances to reduce pollution of freshwater, groundwater, and coastal zones. In addition, overuse of pesticides and fertilisers can produce several negative consequences, including damage to ecosystems, biota and human health, and environmental pollution, among others [9-13]. Biodiversity loss is taking place rapidly due to various human activities, agriculture being one of them $[9,10,14,15]$, and for this reason, to ensure food security, as well as for other non-anthropocentric reasons, it is crucial to reconcile agricultural production and biodiversity conservation.

"Humanity is waging war on nature" is the more direct, non-academic language used by the Secretary General of the United Nations, Antonio Guterres, who stated bluntly "Making peace with nature is the defining task of the 21st century. It must be the top, top priority for everyone, everywhere" [16].

However, globally, agricultural business generally appear to have difficulties in calling a truce: market influences, supported by policy, have resulted in increased farm size and vertical and horizontal integration [17], as well as intense power concentration in the inputs and distributor ends of global supply chains [18], leaving little bargaining power for small and medium farmers. Agricultural liberal market policy measures in Europe (and elsewhere) have often favoured increased production and intensification at the expense of biodiversity and ecosystem services [19]. According to the European Environmental Bureau (EEB), Dupeux [20], and Poore and Nemecek [21], food systems are responsible for $26 \%$ of greenhouse gas emissions worldwide; they not only contribute to climate change, but also to the deterioration of ecosystems and unprecedented levels of species loss [22]. Natural resources in which farmers rely on are under such pronounced overexploitation that an extinction crisis is a threat [23]. The same EEB report observes that "European 
farmers are lurching from crisis to crisis with an ageing farming population which struggles to attract new young farmers".

All of these influences have had an impact on agri-food systems, from seed to fork. Farmers, their advisors, and their relevant AKIS, which include networks of individuals, research and education, bridging institutions, business and enterprise, and the enabling environment institutions and policies, have also been influenced by agri-food system pressures and the demand to increase production and optimise efficiencies, while at the same time, becoming aware that farming activity depends on ecological sustainability. AKIS is considered a key concept in identifying, analysing, and assessing the various actors in the agricultural sector, as well as their communication and interaction for innovation processes [24]. It should be noted that certain literature also refers to Agricultural Innovation Systems or "AIS", which are similar to AKIS, but with a more pronounced focus on system innovations [25]. For the purposes of this article, we will refer to AKIS, which is understood to include agricultural knowledge, and the various technical, organisational, social, and institutional organisations involved in innovation and transition processes.

Calls for changing agri-food systems are increasingly framed in the context of sustainability transitions [4,26-28], including in the agri-food sector [1,29-34]. The Sustainability Transitions: Policy and Practices report was published in 2019 by the Sustainability Transitions Research Network (STRN) [35], and studies a wide range of sectors, agriculture being recently added as an "official" group. Sustainability transitions are sociotechnical transitions that are associated with sustainability targets and that switch systems to more sustainable modes of production and consumption [28]. They deal with fundamental changes that are complex, multi-dimensional (technical, organisational, institutional, political, and sociocultural), and generally are long-term and uncertain [36,37]. They can be disruptive, contested - that is, they involve tradeoffs for different actors—and affect different parts of the value chain. Sustainability transitions and pathways are also highly dependent on the context of sectors, places, and social or technical maturity/readiness levels. These transitions are a multi-actor process, which co-evolve, navigating between both stability and change. The sustainability transitions literature does not ignore that power and politics also play a central role, although it is not reductionist.

Coupled with the framework of sustainability transitions, is the multi-level perspective (developed by Rip and Kemp 1998 [38]) with reference to climate change, and further developed by Smith et al. [37] and Geels [39,40], which develops three central concepts that will be utilised in this paper: niche, regime, and landscape. Niche (micro level) refers to small networks of actors that carry out innovative activities and by virtue of their experimental, limited nature, or shared "space" are protected from the dominant systems, whether the market or otherwise. Regime (meso level) refers to the dominant, incumbent social-technical system including formal and informal rules. The regime includes technologies, institutions, and actors, and they offer coherence, stability, and are not prone to radical transformation, but rather incremental adjustments. Landscape (macro level) refers to broad societal trends, macro economic trends, political developments, cultural, and societal values, and exogenous events, such as crises, demographic changes, climate change, etc. Changes in the landscape can open up opportunities for niches and put pressure on regimes to change [41].

Because of the context dependent nature of sustainability transitions and the various levels in which they operate, existing AKIS may enhance innovation niches to support sustainable transitions across the various systems implicated in agricultural activity through leveraging collective and integrated innovation from different levels of activity [25].

This article focuses mainly on farmers and the production phase of agriculture. While some criticism has been directed at scholars for not "adequately addressing food systems" [5,26,41], by involving the whole of the classic supply chain actors, such as consumers, distributors, and processors, it should be recognised that there are multiple systems at play in agri-food, which are not focused only on linear supply chain relationships, but also on agro-ecological, socio-ecological, sociotechnical, or nexus systems (i.e., food, water, energy), 
which are often implicated mainly in production activities. Analysis of the production stage, as this article does, is not necessarily based on a more limited approach to systems, but rather on various different interacting systems that may include non-market as well as market systems. In particular, the production system, which encompasses much more than agricultural production activity within farm boundaries, also implicates social-ecological or human-environment systems that describe human behaviour and the interaction with other systems, such as the water, biodiversity, and ecosystems, as well as sociotechnical systems, where ecological, biophysical, and geographical dependencies occur [25,30,42]. Necessarily, any study of transitions, even in the agri-food sector, implicates a wide range of disciplines [14,43-45].

Returning to the main theme then, of connecting farmers to nature, this paper engages with the imperative to "make peace with nature" from what may seem a rather surprising or unsuitable candidate for an argument for sustainability transition: an intensive agricultural system involving 32,000 ha of fruits and vegetables (plastic) greenhouse farming in a semi-arid region of Almeria, South-East Spain.

Part of the process of "making peace with nature" implies a deeper understanding of and relationship with nature. "Connectedness" to nature is proven to have a positive impact on an expanded sense of valuing non-human species and also leads to pro-environmental and conservation behaviour [46,47], particularly amongst farmers [48]. This connection has been defined as the extent to which individuals include nature in their emotional and cognitive perspectives $[49,50]$. In arguments for a transition to a more sustainable agriculture, much emphasis has been put on consumers and their power to reshape production through market demand [51,52]. In agroecological transitions, the consumer relationship to growers is noted as being transformative [53]. However, this begs the question of what a relationship with growers will achieve if the growers themselves are not connected to nature and engaging in sustainable agriculture.

As a consequence of industrial agri-food systems, coupled with demographic trends that have seen a significant shift of people from rural to urban areas, not only has there been a disconnection of a large proportion of the European population with agroecosystems, within which such agricultural activity is carried out, but farmers themselves have also found themselves disconnected from nature by virtue of their participation in conventional agri-industrial production $[54,55]$. A farmer's relationship with nature is a fundamental cornerstone of any attempt to transition to sustainable agricultural systems. Consequently, the relationship with nature is also influential in shaping other people's understanding of agriculture, including, but not limited to, local communities, consumers, and civil society. The question then is whether farmers themselves can reconnect with nature through the adoption of more sustainable agricultural practices, and more importantly, how, given the constraints of markets, path dependencies and lock-ins. Recent European initiatives, such as the Farm to Fork or the European Green Deal, have refocused on the importance of farmers in sustainable agricultural transitions, as well as their advisors and other AKIS [56], but putting this into practice at a system level is challenging.

This article addresses this challenge by combining several analytic approaches, which are then applied to four niche initiative case studies.

\section{Material and Methods}

This article employs mixed methods, triangulating desk research, experimental and project results, and is centred around four case studies representative of related niche activity within the Almeria intensive farming system. It is a result of a multi-actor authorship approach. We use several overlapping frameworks to explore these niches: sustainability transition frameworks [57]; multi-level perspective [39]; and Gliessman's five levels of food system change [53], coupled with multi-actor AKIS, as well as Geels [36] and Pereira et al.'s [58], analysis of multi-level transitions and the dangers of lock-ins [59], which inhibit transitions. 
Gliessman's five levels of agroecology provide us with a conceptual link for classifying "levels" of agri-food system change based on the relationship of growers to other actors in food systems and also their role in bringing about sustainability transitions through incremental and transformational change [53] (Figure 1). Level 1 is concerned with optimising resource use efficiencies, level 2 with the substitution of conventional practices with agroecological practices, and level 3 with the redesign of agroecosystems, the latter being part of transformational change. The fourth and fifth levels go beyond the farm into the food system and the societies in which they are embedded. These five levels altogether represent a roadmap to outline a process for transforming a food system into an agroecological one.
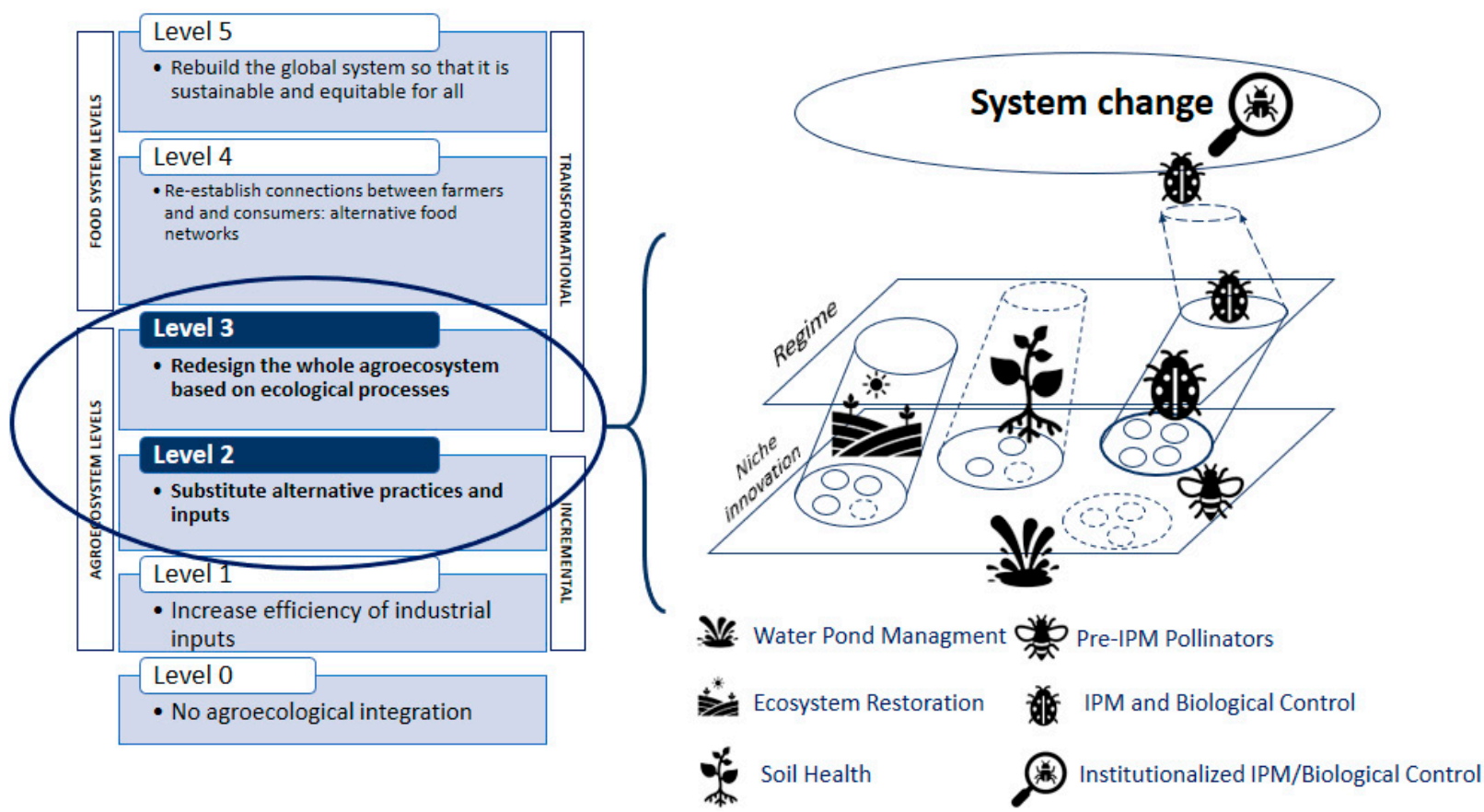

Figure 1. Focus of article and Almeria's location in the five levels of agroecology and four niche experiments in the multi-level perspective; authors' elaboration based on Gliessman, S. [53], Geels, F.W. [36], and Pereira, L.M., et al. [58].

This article is concerned with the implementation of level 2 (via niche innovations and experiments) and the transition to level 3, wherein growers transition away from conventional agricultural systems. The multi-level perspective, previously described above, will be utilised to set out the development necessary to effect the transformation from one level to another [36], considering niche activity, existing regime characteristics, and landscape, corresponding to: individual, collective, and organisational behaviour of farmers, their advisors, businesses, and other actors in discreet experiments, projects and activities; the dominant pattern of actors and structures in agri system; and broad exogenous factors; or prevailing meta narratives, respectively.

The inclusion of AKIS provides a context in which to describe in more detail the multi-actor approach, and more importantly, the local system in which the niche activities operate to bring farmers and their advisors closer to nature, so as to bring about sustainable transitions. Activation of resources and capabilities within AKIS, along with co-creation and collective action through niche activities, have begun to create shared visions of more sustainable (and realisable) paths [24,33,60]. More specifically, projects are able to "dynamically configure capabilities" for agricultural systems innovation [61].

In line with the above approach, this consideration of several niche initiatives within the Almeria AKIS related to the greenhouse sector in southeast Spain, is an example of how agricultural transitions can utilise niche activities and the dynamic characteristics of 
farming systems and specific contexts to "reset" narratives and development paths. We also refer to various regional, national, and European projects and initiatives that have been leveraged to accelerate such change, providing a "safe space" to experiment outside of a dominant market logic [61].

Finally, we will consider the outcomes of the four case studies in terms of their transition pathways from niche to influencing a new regime, relying on Geels and Kemp [62], Joffre et al. [59] and Pereira et al. [58].

\section{Results and Discussion}

\subsection{Application to Almeria Agricultural Production System}

Almeria represents a particular agricultural development model, one which in the last 50 years has undergone a profound technical, socio-economic, and agricultural system transition and transformation. Five decades ago, one would have found subsistence farming conditions. It was one of the poorest regions of Europe, suffering from inept policies of autarky and the isolation of Franco's dictatorship. Many of its inhabitants had to migrate to other parts of Europe and the Americas to survive. However, in the 1960s and 1970s, the installation of electrical infrastructure allowed more efficient exploitation of underground aquifers and the Franco government put into place development schemes, which lured farmers to the area. Rudimentary greenhouses were set up using cane sticks and old posts from a defunct table grape trade, with plastic strung over the top. Cooperative finance, based on knowledge of the German credit cooperatives, was quietly set up for the farmers by a small group of people who were searching for alternatives between fascism and communism $[63,64]$, as well as markets so that farmers did not have to sell individually, at the low prices of the farm gate, to intermediaries. With the death of Franco in 1975, other institutional structures were put in place, such as an export association, an experimental agricultural farm initiated by the cooperative bank, and the establishment of farmer owned agricultural cooperatives, encouraged by local and state entities [65].

Throughout the remainder of the 1970s, technical, institutional, and socio-economic infrastructure was put into place. By the 1980s and 1990s, Almeria's production was increasingly influenced by European (and then global) trade, subject to increased competition and downward pressure on prices and increased calls for higher production [66]. Almeria agriculture has often been characterised as an agricultural industrial district or cluster [67].

Over the last five decades, Almeria has fostered an economic base of family farmers, which still survives to this day. The farmland is divided into small side-by-side parcels amongst 16,000 small-scale family farmers, each cultivating an average of approximately two hectares. These small growers are predominantly organised around packaging and marketing cooperatives and producer organisations, and the production activity is complemented by a significant agricultural auxiliary industry (plastics, seeds, fertilisers, natural enemies and pollinators, etc.) which is almost exclusively non-cooperative. The cooperative entities play an important role in the AKIS, as do public and private advisors, public and private research centres, universities, and companies.

The share of product marketed by cooperatives, as opposed to capitalistic companies, has actually increased [68]. Over $70 \%$ of sales are handled by marketing cooperatives, with an annual turnover of over EUR 2200 million and annual production of over 3.5 million tons (the total being somewhat higher if auctions are included). More than 90 farmerowned cooperatives are currently operating in areas providing either specialised or general services. The agricultural cooperatives of Almeria represent $21 \%$ of all fruit and vegetable $(\mathrm{F} \& \mathrm{~V})$ cooperative turnover in Spain, and about $75 \%$ of Almeria's production is for export, accounting for $25 \%$ of the total Spanish F\&V exports.

The farmers and their cooperatives have evolved locally, generating networks among the farms and interrelationships with the other stakeholders in the sector and territory. There are cooperative associations (e.g., the Association of Fruit and Vegetable Producers Organisations of Almeria, COEXPHAL, and the Federation of Agrarian Cooperative Entities of Andalusia, CAA), as well as research institutions such as IFAPA, the Cajamar cooperative 
bank experimental station, and the University of Almeria. Collectively, they form an intertwined AKIS cluster.

In the last ten years, due to both market and social forces, various actors in the sector have become aware of the need for increased economic, social, and environmental sustainability [69]. Like much of European agriculture, the product has become commoditised and the margins increasingly small. Farmers and their cooperatives and producer organisations constantly seek new ways to optimise resources, differentiate products, and compete within the intensive agricultural system in which they find themselves. However, there is a growing sense that the optimisation of resources (Level 1), is not enough to ensure sustainability and that the system itself is in need of change.

Over the last 50 years, agriculture has been under scrutiny due to the impact it has on natural ecosystems and its repercussions on global warming. Several decades of "Green Revolution" principles have led to a high level of intensification of agricultural systems. Almeria's intensification began in the late 1970s as a response to poverty and food insecurity, and technologies that allowed easier exploitation of natural resources, gaining strength in the 1980s when markets liberalised, generated a sudden growth of the greenhouse area during the 1990s. Recent works highlight the involvement of such intensive agricultural models in the decline of biodiversity worldwide. For instance, insect biomass is falling, with an average of $2.5 \%$ annually, and every year, $1 \%$ of species are added to the list of declining ones. Among the main potential determining factors of this decline are habitat loss, agrochemical pollution, the introduction of invasive species, and climate change [70,71]. Habitat loss is the primary driver of insect declines in $49.7 \%$. Chemical pollution, mainly due to synthetic fertilisers and pesticides, not only lowers insect numbers and other biodiversity, but also degrades their ecosystem functions [72]. This trend is worrying, as insects constitute essential items for trophic networks and secure the integrity and sound functioning of the world's terrestrial ecosystems-e.g., by providing USD 400 billion annually worth in 'natural biological pest control' [73].

The Green Revolution was founded on technological ability, based on scientific principles, with the underlying assumption that science was better than nature at providing better conditions for crops. While this assumption has been erroneous, for avoidance of doubt it does not signify a return to subsistence farming. The total area of protected cultivation is steadily increasing in the EU. In 2015 the estimated total area in the EU was about 175,000 ha, and the rate of increase was close to 4.5\% between 2005 and 2013. Although in Almeria province, greenhouses constitute about $\%$ of the total surface [74], the development of intensive horticulture in the province has registered a huge increase in greenhouse surface area along last decades, reaching 32,368 ha in 2020 [75], where two agricultural regions (i.e., Campo de Dalías and Campo de Nijar) comprise up to $85-90 \%$ of that area. The greenhouses in Almeria produce over 3.7 million tons per year of $F \& V$ providing direct employment to more than 40,000 workers annually. More than 250 complementary or auxiliary businesses, both cooperative and investor-owned have been created with a turnover of more than EUR 1500 million. In a relatively short period (50 years), the people of this province went from suffering abject poverty to having a thriving, internationally focused economy [65]. However, this socio-economic development has had certain negative environmental impacts on a region with exceptional ecological value, and at times, this, together with the loss of natural capital, including the maintenance of ecosystem functions, has not been fully recognised by its population or policymakers.

To help to redress this situation, a critical rethinking of the current agro-production paradigm is necessary. During the early 1980s, agroecology emerged as a reaction opposing the current paradigm proposed by the Green Revolution. At that time, the focus of agroecology occurred at the farm level, where farmers were encouraged to increase productivity by substituting agrochemical inputs for sustainable, ecological principles provided by biodiversity. The concept of agroecology evolved during the 1990s to become the 'ecology of the entire food system' [76]. Currently, the agroecosystem view has expanded beyond the farm level to include all participants in the food system, by re-establishing the connection 
between farmers and consumers, while minimising the negative impact of all the actors between both groups. A further step was taken more recently by including a political economy focus to include all aspects of the food system and develop alternatives to the lock-ins that prevent a change in the food systems. The term agroecology is now defined as:

"The integration of research, education, action and change that brings sustainability to all parts of the food system: ecological, economic, and social. It's transdisciplinary in that it values all forms of knowledge and experience in food system change. It's participatory in that it requires the involvement of all stakeholders from the farm to the table and everyone in between. And it is actionoriented because it confronts the economic and political power structures of the current industrial food system with alternative social structures and policy action. The approach is grounded in ecological thinking where a holistic, systems-level understanding of food system sustainability is required". [77]

In this study, we incorporate Gliessman's vision of agroecology (and its incremental levels) to characterise four areas (each one presented as a separate niche study). We explore how agroecology can transform conventional agricultural systems into systems that shield arthropods and other biodiversity, as well as consistently improve both production and environmental outcomes in which farmers are increasingly experimenting, relying on biodiversity-derived solutions through the gradual recognition and appreciation of nature, supported by their local AKIS. Section 3.2 sets out the current problems presented by the conventional agricultural systems, followed by each of the four niche transitions in Section 3.3.

\subsection{Current Problems in Conventional Agricultural Systems}

\subsubsection{Pest Management}

Due to the Mediterranean climate, the high concentration of greenhouses, and the overlap of different crop cycles, the area is extremely vulnerable to pests and diseases. Pest and disease management in greenhouse horticulture is more complicated than in most open field crops because the greenhouse microclimatic conditions and high plant density favour them [78]. In most horticultural crops, there is a prolonged period of harvest, so high pest levels cannot be tolerated by growers at any moment during the crop cycle. Furthermore, most crops are vulnerable to insect-transmitted viruses, potentially causing considerable crop losses [79]. These characteristics have influenced risk-aversion attitudes among most farmers towards pests and diseases, who, until the mid-2000s, based their management on chemical control with pesticides.

However, excessive reliance on chemical management of pests has led to an intensive use of pesticides and to pests developing resistance to insecticides [80]. Excessive pesticide treatments can produce multiple negative impacts on the health of farmers, workers, consumers, biodiversity, and ecosystems. In addition to these direct negative effects, there are potential indirect socio-economic consequences, such as the accumulation of pesticide residues on harvested vegetables. In the past, this has led to severe commercial and image problems, mostly in the form of rejection of Spanish horticultural products in other EU countries [81]. An alternative strategy to managing greenhouse pests with chemicals is biological control. Biological control is based on releasing natural enemies of pests (predators and parasitoids) in the greenhouse, to reduce their numbers and associated damage. The use of biological control in the greenhouse has proven to be a viable alternative to pesticide use from both an economic and environmental perspective [82]. Currently, thirty billion beneficial arthropods are released annually to deliver pest control protection in the greenhouse crops of Almeria. This practice enhances the quality of $F \& V$ consumed in the EU, while promoting pesticides reduction and environmental sustainability.

\subsubsection{Habitat Management}

Greenhouse horticulture is the biggest cause of habitat loss in Almeria. In particular, protected horticulture is clustered over the distribution area of a semi-arid habitat 
characterised by the endemic shrub Maytenus senegalensis subsp. europaea (also known as Artineras). This habitat is under serious threat because over 26,000 ha, representing ca. $43 \%$ of its distribution area is nowadays occupied by greenhouses. As a result, the landscape is highly fragmented and only a few poorly conserved patches of native vegetation remain in the area $[15,83,84]$.

The role of biodiversity in securing crop protection has gained recognition, focusing on the regulation of undesirable organisms by their natural enemies (indigenous predators and parasitoids). The natural biological pest control enabled by biodiversity provides an ecosystem service of extremely high economic value [85]. However, enhancing pest control ecosystem services via the conservation and/or plantation of native vegetation is still a pending subject in the integrated pest management (IPM) programs in greenhouses in Almeria. Currently, as a result of intensive cooperative research and training activity, there are an increasing number of growers interested in planting hedgerows with native vegetation around their greenhouses. These initiatives, coupled with the ecological restoration of vegetation at the landscape level, could serve as green corridors for biodiversity and reduce the habitat fragmentation in the region.

\subsubsection{Soil Management}

In Almeria, sand mulch (or "arenado", as it is known locally) is the main type of soil management with more than $85 \%$ of the greenhouses using it [86-88]. "Arenado" consists of covering the surface of the crop field with an upper layer of silica sand, and a second layer of manure or organic matter underneath. Organic matter amendment application (locally called "retranqueo") is becoming less common over time, mainly due to the work involved in removing the sand layer and the increasing use of mineral fertilisers, which have replaced organic fertilisers in most cases. This fact, together with the common practice of monoculture in the greenhouses of Almeria, has led to a loss of soil health, which has resulted in an increased occurrence of soil-borne diseases and plant-parasitic nematodes in some cases, as well as soil fatigue [54,89]. For several years, the dominant strategy to avoid soil fatigue and reduce pathogen load in soils of Almeria greenhouses has been chemical soil disinfestation, mixing solarisation (i.e., covering the crop area with a thin transparent plastic sheet) with chemical fumigants, mainly metam sodium and dichloropropene, which negatively affect soil biodiversity. This practice is also carried out for preventive purposes with no evidence of pathogens or symptoms of soil fatigue. In addition, the agricultural waste biomass produced by horticulture in Almeria, estimated at 1,370,743 tons annually [90], has led to environmental problems [74,90]. One smart and sustainable practice is the reutilisation in situ of this valuable material as organic amendment, which can also be used for the control of soil pathogens in a more sustainable way compared to chemical soil fumigants [91-94]. Moreover, with this practice, growers contribute to cost savings [95] through the elimination and reduction of dependence on new (and in many cases harmful) inputs.

\subsubsection{Management of Irrigation Ponds}

The United Nations has forecast that freshwater resources will be reduced by $40 \%$ by 2030, generating a critical situation worldwide due to water crisis [96]. Strategies to optimise water management, particularly in agricultural systems, are necessary. In Almeria, most of the water resources for greenhouse agriculture come from underground water (80\%) and the remaining 20\% from seawater desalination plants, transfers, and other sources [97].

The lack of water resources, especially surface waters in this semi-arid region has generated the need to store water for its intensive cultivation system, which has resulted in the creation of a large number of water reservoirs and artificial irrigation ponds, which feed efficient drip irrigation. The expansion and intensification of irrigated agriculture has given rise to the construction of a high number of artificial irrigation ponds in Mediterranean regions. Over 8700 ponds have been inventoried in Almeria, most of which are used for irrigation and located in the coastal areas where greenhouses have spread [98]. 
Clogging of irrigation tube emitters is considered to be one of the most serious problems for drip irrigation systems and is usually more severe when treated wastewater is used [99]. This problem is closely related with water quality characteristics, particularly with the presence of suspended solids and algae [99,100]. In this sense, water and pond management by farmers is crucial to achieve good water transparency and quality characteristics. Maintaining submerged aquatic vegetation (SAV) (i.e., plants that grow completely under water) in water ponds can reduce clogging while improving water quality, without the need to use biocides, but to date a minority of farmers are aware of this technique [98].

\subsection{Four Niche Experiments and Innovations to Transition from Conventional Agriculture to Agroecological Systems}

In the transition to a more sustainable society through a reconnection to nature through agriculture (the subject of this special issue), the relationship that farmers have with nature, expressed through production approaches and practices, and their collaborative activities with related organisations is fundamental to changing the agroecosystem-nature relationship. To document these transitions, we explore below the components and process of four niche developments, which create the foundation for a transition to a more sustainable system.

\subsubsection{Niche 1: Transitions in IPM and Biological Control}

The first important step before the uptake of IPM in Almeria greenhouses was the introduction of bumblebees for pollination in tomato crops. Until bumblebees were available for natural pollination, tomato plants were pollinated manually [101] consuming 20 labour days per hectare per month. In contrast, natural pollination by bumblebees offered a more profitable option, with lower production costs, increased yields and improved fruit quality [102,103]. In Almeria, after a few years of commercial small-scale trials, bumblebees were massively introduced in tomato crops around 1995 [104,105]. Some initial tests with bumblebees were not successful because of the lack of technical knowledge. Furthermore, there was little experience concerning the transition towards successful biocontrol in greenhouses with a long history of chemical management. For these reasons, the results with biological control initially were unpredictable, and the success rate was low [106], often leading to contrasting opinions on biocontrol efficiency amongst the growers. However, the emergence of the auxiliary industry and technical support they brought, as well as a supportive AKIS, helped to enable change. The presence of natural pollinators obliged greenhouse tomato farmers in Spain to radically change their pest control system, since many of the formerly used pesticides were totally incompatible with the bumblebees $[105,107]$. Thus, for the first time, growers reduced the number of pesticide treatments, and substituted broad spectrum products for more selective and/or less persistent pesticides to respect the bumblebees [104]. In crops other than tomato, pesticide use was extremely high in greenhouses in the 1990s, exposing farmers and workers to toxicological risks. According to Parron et al. [108], 37\% of farmers who applied pesticides, showed toxic signs and symptoms after spraying.

In this regard, working with pollinators helped farmers to experience the behaviour and associated benefits of bumblebees, possibly improving their attitude towards insects, reducing pesticide usage, and facilitating the transition towards an IPM system, as it similarly occurred in other countries (e.g., Beck et al. [109]). In other words, the introduction of pollinators facilitated the transition to the biological control of pests and diseases in greenhouses.

In Spanish greenhouses, biological pest control first became important in sweet pepper crops (Capsicum annuum), where the most important pest was thrips (Frankliniella occidentalis), which damages fruits and spreads economically important viruses [79,110,111]. Perceived as a major threat by farmers, their presence caused a significant increase in pesticide use, which produced complete resistance of thrips to most available active ingredients [80,112]. The massive use of insecticides caused intolerable levels of pesticide 
residues on the fruits, leading to major economic consequences for the horticultural sector. In 2007, the rapid alert on food safety was issued by European authorities after isofenphosmethyl residues were found in sweet pepper from Spain [81,113]. Immediately after this incident, the regional government reacted by creating a surveillance program to monitor illegal pesticide practices [114], and fines were imposed on 24 fruit export companies and 25 farmers in Almeria [115]. In response to market pressure, companies and growers looked for alternatives to chemical control, but the transition was neither easy nor automatic, since new tools were needed for pests and diseases management.

Ultimately, a number of factors resulted in the broad adoption of biological control programmes in sweet pepper, which is primarily based on the release of mass-reared predatory mites and bugs. This system had already been researched and fully working in the early 1990s in greenhouse crops in northern European countries [81]. However, this system needed thorough adaptations to enable massive implementation in the south of Europe. New biocontrol tools had to be developed against pests that were not present in the Northern countries. Since the first successes of IPM in northern countries, there was a clear interest from official research and extension institutes, such as the Universities of Granada and Almeria, and the regional government's institute for applied horticultural research (IFAPA) [116,117]. Research projects, such as BIOPROTECT, 'Biological Control in Sweet Pepper and Strawberries', were valuable for the optimisation of biocontrol, while other results showed the growth inhibiting effects of pesticides [118].

During this period, and until the mid-2000s, important advances were made: biocontrol companies made significant economic investments to guarantee the availability, quality and competitive selling prices from 2004 onwards, of key natural enemy species, as well as to better understand the effects of pesticide residues on the development of natural enemy populations $[106,114]$. Other AKIS actors and initiatives included government policy on economic subsidies and the coordination of technical seminars, where public research centres, cooperative organisations, and the private sector taught more than 750 field technicians over two years how to successfully establish biological control programs in greenhouses [114]. The result of all these factors produced an exponential increase in farmers' adoption of biological control in Almeria, from 8\% in the 2006-2007 harvest to almost $85 \%$ of a total of 8000 ha of sweet pepper in 2008-2009 [106,114].

A few years afterwards, the application of the Directive 2009/128/EC in 2014 resulted in an additional reduction of the use of pesticides and increased use of biocontrol agents. Growers increasingly moved from chemical-based crop protection to novel biological pest control practices, reconnecting with the benefits of nature-based solutions. Research to test the efficiency of new strategies and/or new biological control agents was carried out by universities and biological control companies after the wide scale adoption took place around 2007 [113,114,119]. These studies, combined with the technical assistance carried out by technicians from biocontrol companies and field advisors contributed to reinforce biocontrol uptake by farmers and expansion into other crops.

More recently, H2020 projects, such as NEFERTITI (www.nefertiti-h2020.eu; accessed on 5 October 2021) and IPMWorks (www.ipmworks.net; accessed on 5 October 2021), have contributed to increase farmers' and technicians' understanding of the functionality of biological control techniques in most crops through demonstrative, participatory activities in commercial greenhouses. Both projects share a common view (also shared with the EU Green Deal) about the need to reduce the amount of pesticides used and to substitute chemical control for alternative, sustainable practices, such as biological control. Feedback received during field demonstrations suggest that a large majority of participant farmers understand and are keen on improving their IPM practices. It is becoming common among farmers in Almeria to be able to recognise a wide diversity of species of natural enemies, secondary pests and other insects, which shows increasing interest in biodiversity. Throughout the activities carried out in the field, groups of farmers, technicians and other actors share their experiences and know-how on aspects related with biodiversity and biocontrol strategies, thus deepening their connection to nature through the appreciation of the 
ecosystem services (i.e., pest regulation) that beneficial arthropods provide. COEXPHAL, the association of cooperatives and producer organisations, have actively contributed to training and knowledge exchange among > 1000 farmers, and the interprofessional, HortiEspaña has launched a collaborative and multi-actor campaign of biological control campaign (www.ilovebichos.com accessed on 5 October 2021). The joint effort between cooperatives, auxiliary industry, administration, field advisors, research centres and universities, and, most of all, an important number of proactive farmers, made possible the transition to IPM. Currently, in Almeria, there is a significant adoption of biological control in most greenhouse crops, with $50.5 \%$ of the crop surface using it [75].

\subsubsection{Niche 2: Transitions in Ecological Restoration and Landscaping for Pest Control}

Non-crops habitats could provide growers with ecosystem services like natural pest control and benefit biodiversity at a small scale [120]. However, in protected horticultural systems growers have been reluctant to incorporate margin habitats near their greenhouses because numerous species of weeds are known to harbour both pests and plant viruses transmitted by insects [121]. On the other hand, results have demonstrated that the main viruses affecting greenhouse crops in Almeria are not found on native perennial plants [122]. Thus, restoration habitat by design in Almeria landscapes seeks to replace these weeds by integrating perennial native vegetation with greenhouse landscape to disadvantage pests, and advantage the natural enemies that attack pests, while biodiversity is enhanced. In this sense, IFAPA together with the cooperative Cajamar Foundation co-led the knowledge, innovation, key findings, and outlined plans with local governments for future adoption measures of integrating native vegetation around greenhouses.

With the reduction of broad-spectrum insecticides since 2007, and application of the general principles of IPM in the EU (Directive 2009/128/EU), naturally occurring beneficial insects began to colonise the crops spontaneously, but also, other pests simultaneously emerged in protected horticulture. With the increasing recognition that pest management needs to be considered beyond the greenhouse boundary, growers sought information on the role of biodiversity as a source habitat for natural enemies and pests. Therefore, the following step to biodiversity implementation was to ascertain how pests and natural enemies used native vegetation in greenhouse surroundings. To fill this knowledge gap, the RECUPERA 2020 European funded project entitled "New technologies to increase the efficiency of biological pest control in greenhouse areas" sought to identify the key native shrubby insectary-plant species for revegetation programs among greenhouses. To do this, four plots arranged in a semi-natural patch were newly planted among greenhouses. The patch was designed to simulate plant species associations naturally [123,124]. Plant species chosen had to meet a range of criteria for enhancing pest control: (1) non-host for plant viruses; (2) provide refuge and food for natural enemies, e.g., phenology flowering, architecture, provide nectar and pollen, shelter, flower colour, flower morphology, etc.; (3) native to the region; (4) commercial availability; and (5) workable around greenhouse practices [125]. Finally, 28 key native plants were identified from 18 different botanical families, suitable for habitat restoration by design in Almeria horticultural production systems. More than 1000 growers, advisors, agricultural school students, researchers, and others, have visited these ecological infrastructures since they were planted in 2010 and expanded in 2015.

Research outcomes indicated that two of the most important greenhouse pests had consistently lower abundance through the year in native plants than in crops. These results confirmed that the studied plant species were not a major source for pests' reproduction [123]. In addition, models showed that certain predators were using these plants to prey on both pests [123]. Native plants also hosted other potential providers of pest regulating services [124]. Research also revealed the tight interdependence of diversity above ground vegetation and soil biodiversity [126] and that soil biotic communities might provide benefits to pest biological control, for instance, by improving indirect plant defences and enhancing recruitment of generalist natural enemies [127]. The RECUPERA project 
subsequently triggered the project "New Biological Control Strategies against Aphids in Greenhouses: Ecological Infrastructures and Disruption of the Ant-Aphid Mutualism", funded by the Spanish National Institute for Agricultural and Food Research and Technology (INIA), which aims to use stable isotopes as an insect marking technique to explore pest and natural enemy movement from native vegetation to horticultural crops.

Two technology transfer projects aimed to encourage growers to change their practices towards biodiversity implementation: (1) "Participatory innovation for protected agriculture (PP.TRA.TRA201600.9)" funded by the EU-FEDER program, and (2) the BIOPLAN project "Biodiversity and biological control against the effects of global warming in intensive agriculture in the Mediterranean coastal areas", were presented to the climate change call of the Spanish Biodiversity Foundation. The BIOPLAN project involved several pilot projects where growers were interested in setting up hedgerows with native vegetation on their greenhouses. Finally, a recent Spanish EIP-Agri Operating Group project GOIDEAS "Implementation of ecological developments for sustainable agriculture" (www.goideas.es; accessed on 5 October 2021) illustrated the benefits of vegetation management around greenhouses, which will encourage more growers to plant hedgerows in their farms. Scientific impact, training impact, and dissemination impact has been achieved by the development of two applications for smart phones for promoting applied (IFAPA GUIA) and natural pest control (PlantEN), and a webpage (https:/ / www.goideas.es/; accessed on 5 October 2021) for promoting the plantation of hedgerows in Spanish Mediterranean agricultural systems. Technology transfer talks (>50 talks), training for students $(>2500 \mathrm{~h}$ ) and dissemination additionally supported the initiative. Finally, all of these changes carried significant implications for local-level governance: for instance, regulations that oblige the establishment of hedgerows in the surroundings of new creation greenhouses (B.O.P. of Almeria number 148 of 3 August 2017); and the existence of incentives by regional administration to subsidise the establishment of green infrastructures (BOJA number 69 of 11 April 2017).

As a result, the horticultural sector is increasingly interested in the biodiversity concept and associated benefits of native vegetation, with over 80 growers applying for design of ecological infrastructures. Once growers have expressed interest in these strategies, they require support to design appropriate functional hedgerows able to act as habitats for the natural enemies, but also adapted to their needs. To respond to this need, IFAPA and Cajamar Foundation developed in 2020 a new tool, DiseñEN, which is a free DSS, (www.dise nen.es; accessed on 5 October 2021), which helps anyone interested, without any knowledge about plants or arthropods, to design a habitat for the natural enemies adapted to the characteristics of their farms. Interest is increasing, and in the 2021/22 season, over $100 \mathrm{~km}$ have been planted in total. For instance, the Association of Producer Organizations of Andalucía (APROA) offers a specific service of revegetation by design to their affiliated members. Increasing interest in revegetation by design has created new job opportunities for local nursery companies that specifically offer native plants for pest control. Currently, most biological control companies offer insectary plants and other services to promote biodiversity for biological control management in greenhouses. Similarly, a number of farmers' cooperatives, cooperative associations (COEXPHAL), and environmental associations (ANSE), are engaging growers about how to integrate biodiversity in and around their greenhouses. Finally, local agricultural schools include landscape management for biodiversity issues in their formation programmes.

Nevertheless, important work remains to be done related to the connectivity of natural vegetation patches through hedgerows. One important task is to give awareness about the available agri-environmental aids which let us increase revegetation by design at a higher scale. A survey carried out about 91 growers showed that they considered these aids useful (GO IDEAS, unpublished data). Moreover, almost $80 \%$ observed an increase in useful fauna present in the crops, and more than $70 \%$ of growers reduced the number of phytosanitary applications. The most notable result was the willingness of growers to carry out actions by themselves, aimed at achieving more sustainable horticulture even though they had not applied for any aid, for example, using biological control, or implementing measures 
to promote functional biodiversity in their crops. Many growers are starting to consider other biodiversity conservation and are starting to set up nesting boxes to encourage the presence of pollinators, birds, and bats, which indicates significant improvements in growers' perception of nature.

\subsubsection{Niche 3: Transitions in Sustainable Soil Management}

Soil health [128] takes into account the importance of a living soil. Healthy soils contain a high soil biodiversity and are more resilient to constraints, such as pests and diseases. Sufficient soil organic matter (SOM) content is the basic factor for this because it is the first level of the soil food web. Consequently, SOM and soil biota are considered essential to maintain and improve agricultural soil health and fertility [129,130]. Thus, sustainable greenhouse soils management should favour soil biodiversity and avoid the use of environmentally harmful substances and materials [131]. The norm among the majority of Almeria greenhouse farmers is to disinfect the soil to reduce pathogen load, but also to avoid soil fatigue. A total of $98 \%$ of farmers disinfected their greenhouse soils in the 2013/2014 season, once per year for $63 \%$ of the cases, and every two years for $28 \%$. The largest proportion of farmers prefer using a combination of solarisation with broad spectrum chemical disinfectants $(46.1 \%)$, [87,88,132], which negatively affect soil biodiversity. However, there has been a slight gradual transition in the techniques used to manage the soils, from a paradigm based on using chemical disinfectants to avoiding their use or substituting them for other, more sustainable methods. The impact of soil health loss, together with the EU restrictions on the use of fumigants, as well as the demands of European markets, demanding healthier and safer products, including organics, has over the last 20 years changed the perception of soil as being an inert substrate to an agroecological concept, where living organisms with different functions, are necessary to maintain the fertility and health of soils and crops. Local research and extension actions have assisted farmers and advisors to become aware of soil health. An additional role has been played by the auxiliary industry, promoting its own biological products.

Biofumigation and (bio)solarisation, as well as green manures and cover crops are considered among the best practices for promoting soil health, with a high efficacy on controlling soil-borne diseases $[133,134]$. In Almeria, an increase in practising soil solarisation (with no organic amendments) was observed between 2006 and 2013, with 30-45\% of farmers applying it in their greenhouses in 2013 [87,88]. During the same year, the use of biosolarisation began to be referenced (i.e., $0.4 \%$ of farmers; [88]). In a national congress held in Almeria in 2004, local scientists reported promising results regarding the management of soil-borne diseases by means of biofumigation and biosolarisation. In 2005, only 180 ha of greenhouses were certified for organic agriculture in the province of Almeria [86]. In 2020, this grew to 3693 ha [135]. This significant increase of organic farming indicates a higher interest of greenhouse growers in biodiversity and sustainability, without losing sight of business opportunities.

Polyethylene plastic (black type) is the most common material used for biosolarisation, also used as the main material for mulching in greenhouses [87]. However, due to the difficulties and costs of plastic residues management, there are few farmers starting to use alternative products based on biodegradable or biocompostable films, paper-based or hay mulches [136,137]. However, these alternative products are more expensive for the farmer, thus limiting their extended use. The involvement of the auxiliary industry (sustainable inputs) reflects the demand of greenhouse growers willing to be more connected to nature, thus avoiding non-degradable materials.

Arenado (sand mulch) is the predominant soil type in the greenhouse sector in Almeria [138]. The frequency of organic matter repositioning (mainly sheep manure) is decreasing [87], and it is increasingly common for farmers to incorporate organic material only below the crop lines, mainly to reduce costs [88]. In addition, a lack of organic amendments use was reported for $28.5 \%$ of farmers surveyed in 2012/2013 season in contrast to $6.5 \%$ for season 1999/2000 [87], and a survey conducted in 2020, showed that only $22 \%$ of farmers 
incorporated manure or plants before planting season (Hortyfruta, unpublished data). In this regard, the benefits derived from the organic amendments [139,140], which has strongly contributed to maintain soil health and fertility in the greenhouses of the province for decades, could also be obtained from other sources of organic matter, such as plant debris obtained at the end of the cropping season. The practice of directly removing and chopping plant debris, but letting the debris on the surface of the sand, is now broadly used mainly by pepper growers. This contributes to cost savings through a more sustainable agricultural practice according to principles of circular economy [95]. Furthermore, the incorporation of the vegetal biomass into the soil provides fertilising elements and improves soil quality [141,142]. When combined with solarisation (i.e., soil biosolarisation) it reduces, or even eliminates, the extra inputs of fertilisers for the correct development of a greenhouse tomato crop [92,143,144], reducing nitrate leaching [94,143], mitigating the soil fatigue and monoculture effects through the restoration of the soil productive capacity [145], while also being economically beneficial for growers. It has also been proven to be an alternative method for the control of relevant soil pathogens in horticultural crops in the area, even when the material used was infested by the pathogen itself [93]. Indeed, studies focused on the impact of biosolarisation technique on soil microbiota conclude that, even when treatments have a detrimental effect on soil fungi and bacteria population, they tend to regrow along the crop cycle [146-148]. In this context, since 2017 there are public subsidies for farmers who use their own crop debris for organic amendments [149], and according to data from season 2013/2014, more than $11 \%$ of farmers reported self-management of plant debris [86], which included its use as organic amendment, as well as for composting. In 2020, new measures had been incorporated as part of the European operational funds for producers' organisations dealing directly with the measure reincorporation of plant debris into the soil. During 2021, a total of 68 ha of greenhouses from farmers affiliated to producer organisations have received this public subsidy (APROA, unpublished data).

In terms of biological control of diseases and nematodes, there is also noticeable change in recent years, with an increase of registered products based on biological microorganisms to control diseases, moving from zero biological antagonists registered in Spain in 2003 to 24 different microorganisms species authorised as fungicides or nematicides in 2021 [150]. In addition to biopesticides, microbiological fertilisers have also increasingly being used in greenhouses in recent years. Most of these products and organisms require specific management, different to the conventional chemical treatments, implying in many cases an advanced knowledge and awareness about life in soils by growers.

The AKIS actors and initiatives include the University of Almeria, IFAPA, and the Cajamar foundation, among others, who together with private research institutions, have been working in cooperation with farmers' associations, growers and advisors, interested on improving soil knowledge and soil agroecological management. In the last 20 years, a number of growers' associations and farm companies have funded research projects focused on soil management and soil microbiology. Other stakeholders have also funded research linked with soil microbiology. These projects always combined research and transfer, and normally concluded with seminars or workshops open to farmers and advisors. Together with other local specific dissemination actions in terms of agroecological soil management, there were over 2200 attendees in more than 30 activities held since 2014, indicating a rather successful outreach. It is worth noting the increase of workshops and seminars in the last two years, under the framework of the H2020 project 'Best4Soil' (https: / / www. best4soil.eu/; accessed on 5 October 2021), which is actively disseminating knowledge on soil health, and promoting, via a growing network of stakeholders, knowledge exchange about the best real-world practices by organising regional and local workshops in which growers, advisers, researchers, students, and educators interact and learn from each other. For the time being, the real impact of these workshops on ready-to-use soil management practices carried out in the greenhouse sector in Almeria is not clear, but their promotion may encourage growers to improve their soil health management, by better understanding the benefits of promoting soil biodiversity, ultimately supporting them to connect with 
nature. The feedback obtained shows a great interest for soil topics and for biological control of diseases, as well as a high receptivity of growers for incorporating innovations. However they are reluctant to incorporate practices that increase the workforce, even if the cost is lower than other practices.

\subsubsection{Niche 4: Transitions in Ecological Management of Irrigation Ponds in Greenhouses of Almeria}

Greenhouse farmers have traditionally used two main pond management techniques in Almeria: dredging and biocide treatment [151]. On the one side, dredging is done to avoid sediment accumulation and preserve all pond volume. On the other side, biocide treatments are used to avoid algae and aquatic vegetation development. These two main techniques have been carried out since the first irrigation ponds were built in the 1970s. There are two main types of ponds in the area, concrete made (oldest and shallowest) and polyethylene-lined (comparatively newer and deeper) [151].

In a study conducted in Almeria to better understand pond management practices among farmers, two thirds of the interviewed growers dredged their ponds. However, this practice was not effective at eradicating the presence of microalgae in the long term, as it was found in $38 \%$ of the ponds after a few weeks, even when biocides were applied [151]. The reduction or suppression of this practice would significantly reduce the economic cost of pond management, while increasing biodiversity (particularly SAV) in ponds [98]. As it occurred with dredging, two thirds of the interviewed farmers in Almeria used biocides [151]. According to farmers, they used this technique to prevent the appearance of biological activity in the water column (i.e., mainly algae and SAV, both perceived by this group as detrimental). Juan et al. [151] found that most farmers with SAV (almost 60\%) applied biocides despite the fact that they noticed that water turbidity increased after their removal [152]. However, some farmers had a positive opinion about SAV (almost 26\% of those who had aquatic vegetation), and conserved it by stopping the use of biocides. Based on their experience, they concluded that SAV presence had a positive influence on the water quality, showing significantly better water quality (clearer water) for drip irrigation. Indeed, results on chemical pond treatment have shown a worsening of water quality for drip irrigation systems since biocides increase the values of planktonic chlorophyll $a$ and total suspended solids [152], key parameters to ensure a correct uniformity of irrigation and reduce the probability of clogging by algae and other organic matter. The use of biocides, such as copper sulphate, keep nutrients available to microalgae in the water column, so their use may favour episodes of algae bloom and death and microorganisms decomposition that lead to reduced water quality. Thus, research indicates that biocide treatments do not improve water quality, and sometimes can worsen it. In this sense, the presence of SAV (e.g., Chara spp.) can improve water clarity for drip irrigation systems by reducing the concentrations of planktonic chlorophyll $a$ and total suspended solids [152]. In addition, many studies show the benefits of the presence of SAV versus phytoplankton, competing with it by reducing available nutrients and producing a clear water column free of microalgae, but also free of sediment, since the roots of aquatic plants help to fix the substrate [153]. Therefore, avoiding or reducing treatments with biocides would favour the presence of SAV in ponds, improving water quality for drip irrigation, while increasing the ecological value of water ponds for biodiversity conservation.

Although there is no data available on the use of pond covers, it appears that it is becoming more predominant among farmers in Almeria, partly because this technique is subsidised through the operative funds for those affiliated to producer organisations (APROA, unpublished data).

However, some farmers have shown positive opinions about SAV, because they realised (through practical experience) that without doing anything (i.e., covering, dredging or treating with biocides), they had optimal water quality in their ponds (and they saved money). Water ponds managed ecologically, by preserving SAV showed better water quality values compared to the other three techniques [152], while at the same time developing 
an authentic aquatic ecosystem with greater biodiversity. Currently, most farmers do not know the advantages offered by the maintenance of aquatic vegetation in irrigation ponds, quite possibly because of the scarce knowledge dissemination activities that have been carried out based on the studies previously done by various research organisations.

The University of Almeria studied different techniques of pond management in the province of Almeria and concluded that of all of them, the maintenance of the SAV contributes significantly to maintaining better water quality while greatly enhancing the environmental value of them [152]. In this way, SAV could provide, at the same time, a shelter for many other species of animals as macroinvertebrates, amphibians, fish, and birds [154]. If adequate dissemination of studies were done, it could help to change the farmers' attitudes with regard to pond management techniques and nature, favouring those that are environmentally sustainable, while avoiding the use of biocides.

The AKIS actors involved in this initiative were public universities in Almeria and Seville (the importance of pond management in aquatic ecology, especially the presence of SAV and phytoplankton and water quality for drip irrigation systems), laboratories of COEXPHAL, the association of producer organisations (study of relationship between fungal communities and pond management), and the EU project IPMWorks (monitor farmers who implement SAV in their ponds with the objective of improving water quality using aquatic vegetation). Dissemination was carried out through local and national farmers' technical journals. Most importantly was the involvement of over 100 farmers, all of whom based their pond management in their practical experience, without any previous knowledge. Techniques used in their ponds were learned from their parents or peers.

\subsection{Summary of Niche Initiatives, Transitions, and Farmers Relationship to Nature}

The transition towards a sustainable agricultural system is not a linear path, but a complex process consisting of distinct phases towards system transitions. Regime systemic change generally emerges after a long period of preparation and trial and practice, where niche experimental innovations form a new coalition at the local production or micro-level of the system. Learning processes and knowledge exchange amongst niche actors are fundamental to create synergies and navigate transitions. Innovations, particularly those tested and demonstrated, start to change the agroecosystem, although some innovations become stunted for lack of uptake. When a "window of opportunity" emerges [58], for example, a new technology, new legislation, or even a crisis, innovation can become more rapidly institutionalised at the regime level. The symbols below in Figure 2 show how niche innovations have progressed in intensive greenhouse agriculture in Almeria.

The four niches referred to in Figure 2 above have had somewhat distinct development paths.

\subsubsection{Niche 1: IPM and Biological Control}

IPM and biological control are already established and are now widespread across most greenhouse crops in SE Spain, with the release of natural enemies for key pests. A consolidated regime exists, heavily supported by auxiliary industry and other AKIS actors (Figure 3). IPM continues to develop as new biopesticides become available across the EU and the pressure to reduce the use of synthetic pesticides continues.

Throughout the years, growers have gained the knowledge and experience needed to manage pests with biological control. Growers now recognise several other positive outcomes: that there are no phytotoxic effects associated with biological control; there is no withholding period after their release; no pest resistance build-up occurs; and releasing of natural enemies is far more amenable to workers, and positive for their own well-being and health $[82,118]$. 


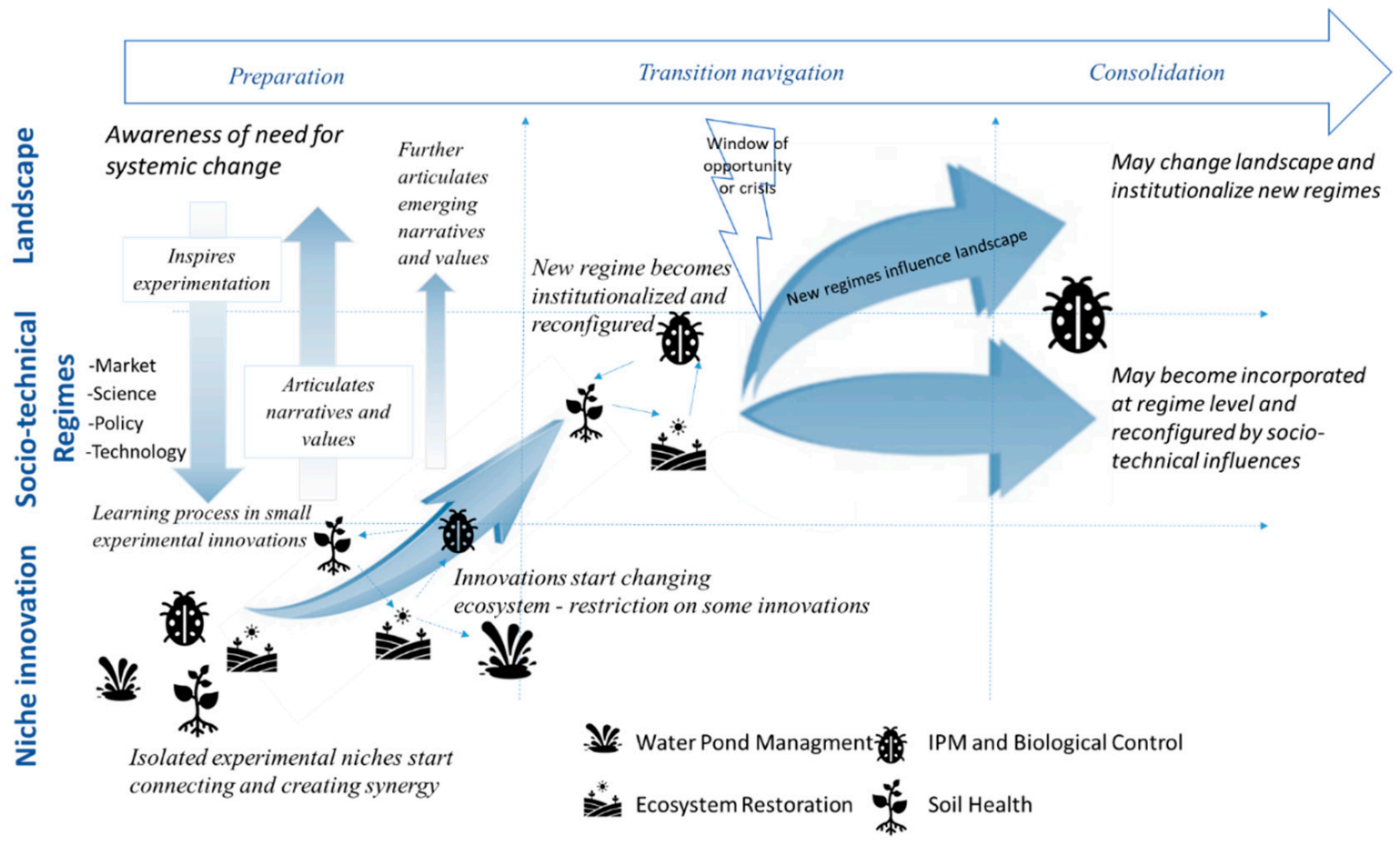

Figure 2. Authors' elaboration based on multi-level concepts offered by Geels, F.W. [36], and niche synergy offered by Pereira L.M. [58].

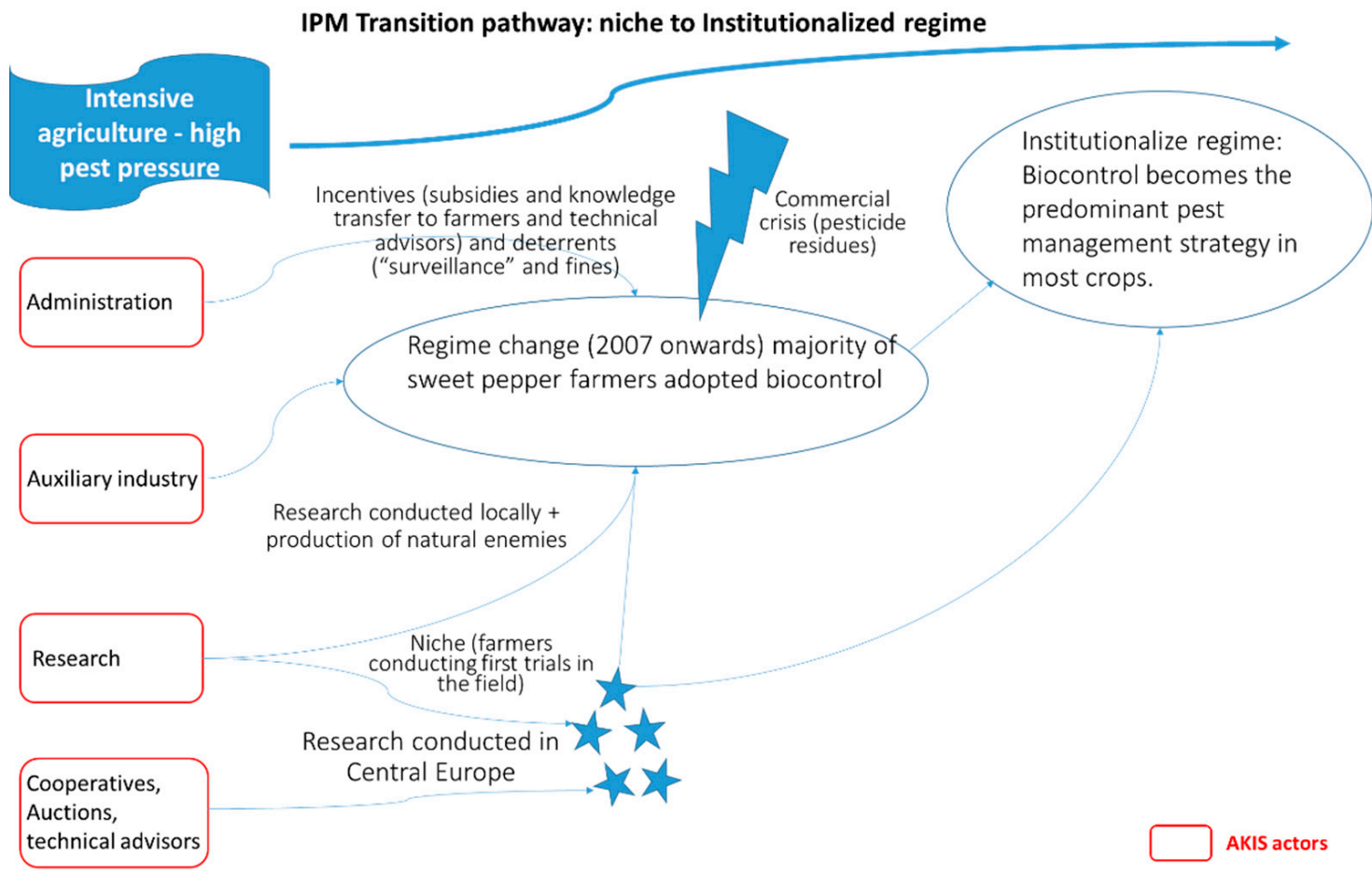

Figure 3. AKIS and IPM transition pathway (authors' elaboration).

The massive adoption of biological control with beneficial arthropods has proven to be an efficient method to address a sustainable pest management system. After starting with the introduction of commercially reared biological control agents, growers now recognise the fundamental role of beneficial species that appear spontaneously in the crops from the surroundings, and have come to at least a functional appreciation of nature. This has led to a whole new approach to pest management, with a leading role for conservation 
biological control and restoration of biodiversity. Thus, Niche 1 has set the stage for further development of Niche 2.

\subsubsection{Niche 2: Ecological Restoration and Landscaping for Pest Control}

Several examples of projects, experiments, demonstrations, and farmers having already planted hedgerows in multiple niche initiatives are evident (Figure 4), but there is no institutionalised regime as of yet, although local legislation requires new greenhouses to plant hedgerows. There is a progressive alignment of elements and a trend (via empirical evidence in the field and scientific/innovation projects) to consolidate the technical advances.

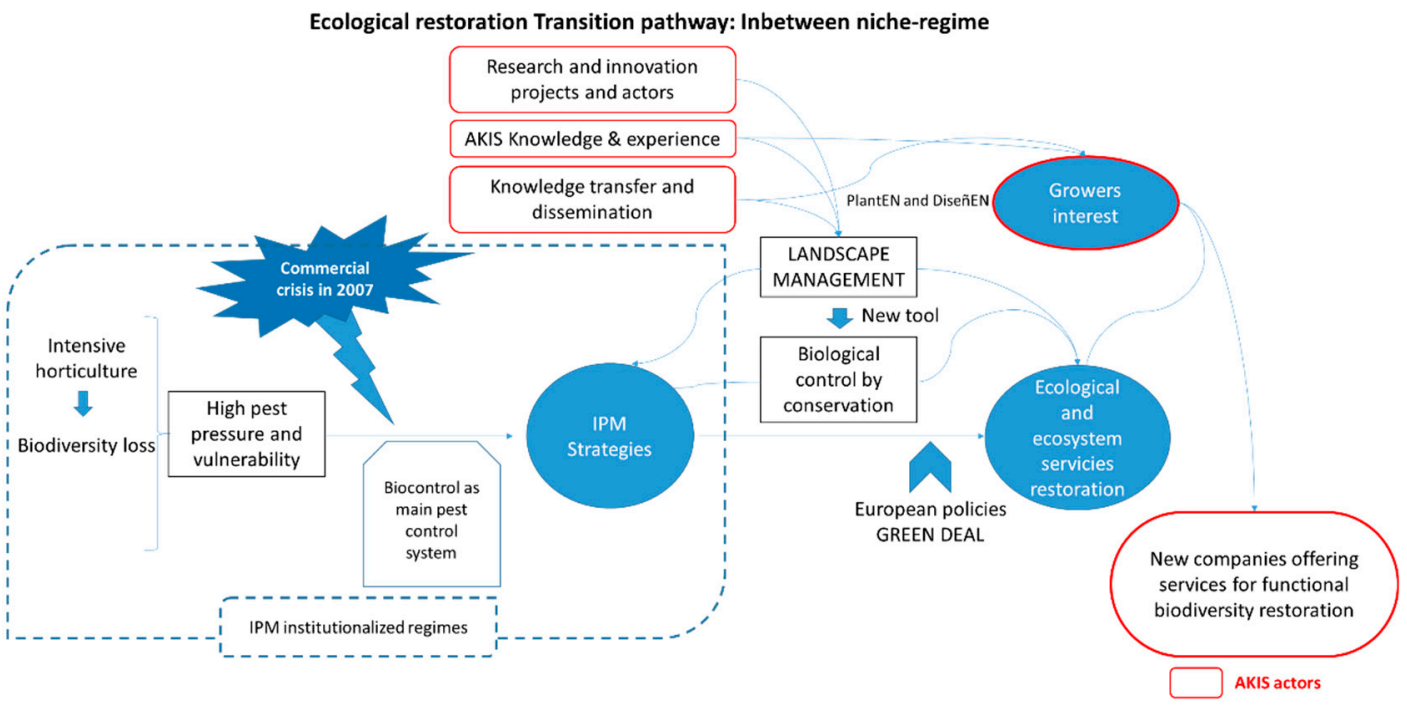

Figure 4. AKIS and ecological restoration transition pathways (authors' elaboration).

The growing criticism of intensive agricultural practices that lead to a deterioration of natural resources and a decrease of biodiversity has progressively led to pressure at the landscape level, where environmental constraints have been put on agricultural activities through more ecological European public policies. These landscape level policies have been geared towards protecting environmentally sensitive areas, improving groundwater quality, and more recently, developing organic farming and/or reducing pesticide use. However, these regulations are still very far from applying truly "ecological" agricultural practices. While the concept of integrated IPM has been accepted and incorporated in public policies and regulations in Europe, signifying not only a regime change, but also a consolidation at landscape levels, a holistic implementation of IPM has not yet been developed. For instance, though applied biological control programs have been successfully implemented in a wide range of horticultural crops in the greenhouse of Almeria, the loss of the natural habitats goes on, and the adoption of the strategies described herein for conservation biodiversity and revegetation by design is still slow and punctual rather than widespread.

Well-designed communication campaigns, applied (greenhouse-level) research, and supportive policies could ensure implementation. Small-scale IPM programs in greenhouses could include the active plantation of hedgerows with native plant species around greenhouses by growers and, at a landscape scale, the regional government should urgently invest in revegetating degraded land and reconnecting habitat remnants. These two actions together would generate interconnected green corridors, able to strengthen biocontrol services and other ecosystem services throughout the greenhouse landscapes. These combined efforts would most likely improve farmers' appreciation of nature through an increased acknowledge of biodiversity and the inherent benefits derived from it. 


\subsubsection{Niche 3: Sustainable Soil Management}

Soil health is a main concern of EU agricultural policies, but few programmes offer specifically the implementation of management practices linking farmers to Nature. However, several research, dissemination and networking initiatives on agricultural soil are currently ongoing in Mediterranean greenhouses because, compared to other greenhouse cropping systems in Northern EU countries, in which crops are mostly grown in artificial substrate or soilless systems, the vast majority of greenhouses in Almeria grow in soil. This fact clearly indicates growers' acknowledgement of the soil as a key factor linked to the horticultural activity. These soils have been managed for over 50 years following the principles of conventional (chemical) agriculture. The two predominant practices have been the continuous application of mineral soluble fertilisers and soil chemical fumigation as a preventive measure to prepare the soil for the new seasonal crop.

However, over the last years, these two practices have been confronted with sustainable alternatives that are gaining interest among the growers: the use of microbiological fertilisers and the implementation of biosolarisation and biofumigation, as opposed to soil fumigation. The increasing scientific and technical knowledge about biosolarisation, biofumigation and the importance of organic matter content in soils, on one side, together with the recognition of the microbiological fertilisers as specific inputs in the national regulations, are facilitating farmers and advisors to gain awareness of the biodiversity of soils and their associated benefits.

Thus, the transition of the model for soils, from a chemically-based model to an agroecological biologically-based model, occurs via two main paths: (1) a path of inputs substitution (level 2 of Figure 1), where mineral fertilisers are replaced by microbiological fertilisers. Simultaneously, as new biocides are being approved by the EU and promoted by auxiliary industry, it might trigger a gradual decrease of current fumigants in the short-tomid term; and (2) a holistic approach path, improving soil health by means of increasing organic matter to enrich soil fertility (mineral and biological functions), managing soilborne diseases and parasitic nematodes using biosolarisation, biofumigation, or organic amendments (level 3 of Figure 1). The coexistence of these two paths (inputs substitution and holistic) with the conventional (chemical-based) path is a realistic scenario for the next several years (Figure 5).

\section{Soil Transition pathway: Inbetween niche-regime}

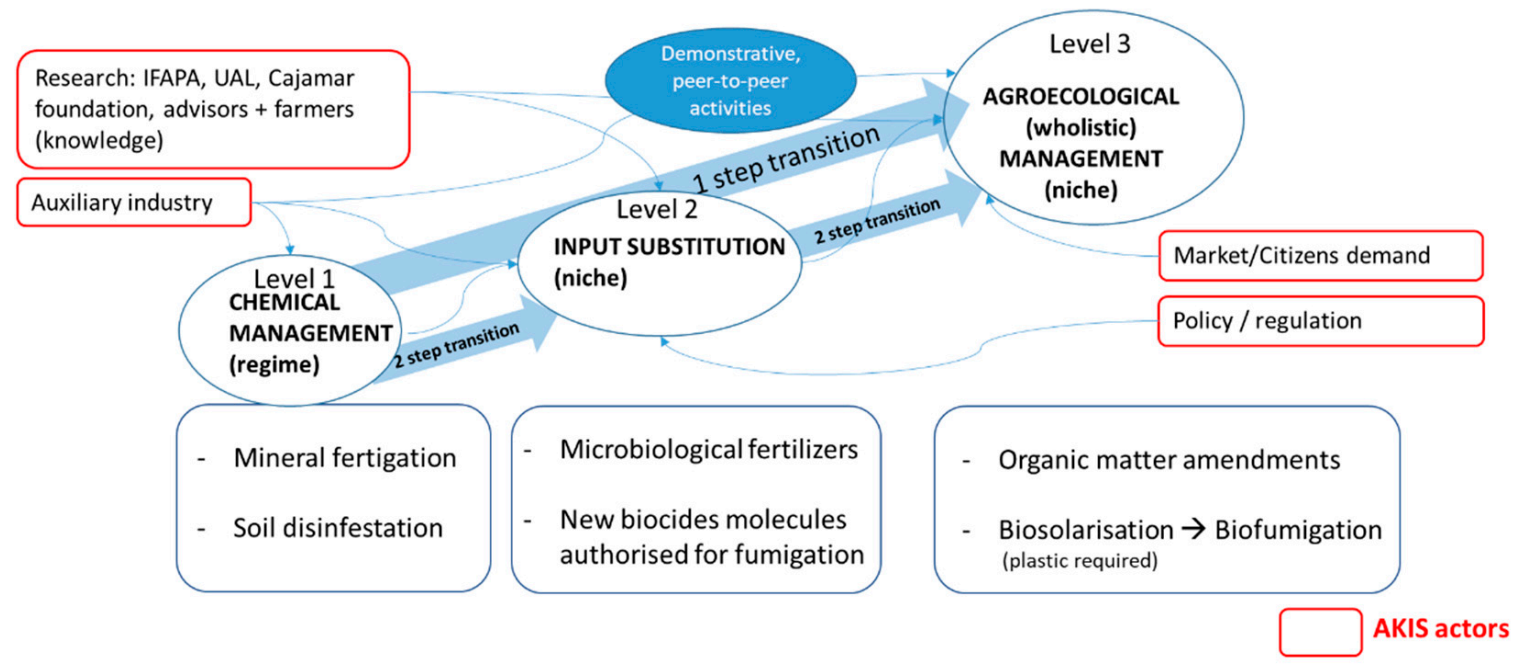

Figure 5. Soil transition pathway (authors' elaboration).

Growers' acceptance of any of these two paths will be primarily based on its profitability, as well as the regulatory (legal) limitations and subsidies. Technical constraints will likely be faced for the two alternative paths to progress, because of the high diversity of 
greenhouses and soil types in Almeria. Therefore, alternative paths must guarantee their success for different crops, crop cycles, water and soil types, etc. To enable most farmers to choose the agroecological transition, the big challenge involves recovering the biodiversity and fertility of natural soils, while maintaining economic profitability.

\subsubsection{Niche 4: Ecological Management of Irrigation Ponds}

Out of the four niches, the ecological pond management is the least developed (Figure 6). Knowledge is available (e.g., scientific papers and even technical reports published), but there seems to be a lack of scaling up, so it remains as an isolated niche experiment. The current pond management practices in Almeria's intensive horticultural systems are misguided in their target to eliminate biological water activity, and have clearly failed at improving the water quality for drip irrigation. The predominant conventional (chemical) practices are not compatible with biodiversity conservation. Pond dredging and biocide treatment are two of the most widespread management practices among farmers with the aim of avoiding biological activity, mainly SAV and algae development [151]. These management practices are not effective in the medium- or long-term as they do not improve nor maintain the water quality for drip irrigation systems. It would be advisable to reduce or eliminate these practices, which could achieve better water quality values of these ponds and increased potential for biological conservation [152]. Scientific studies have shown the importance of irrigation ponds as complementary habitats to natural wetlands, especially in semi-arid regions [155]. Therefore, the naturalisation of greenhouse water ponds (with spontaneous presence of SAV) could have an important environmental role at local, but also regional scale, while providing their important agronomical function by clearing the water for drip irrigation.

\section{Ponds Transition pathway: niche}

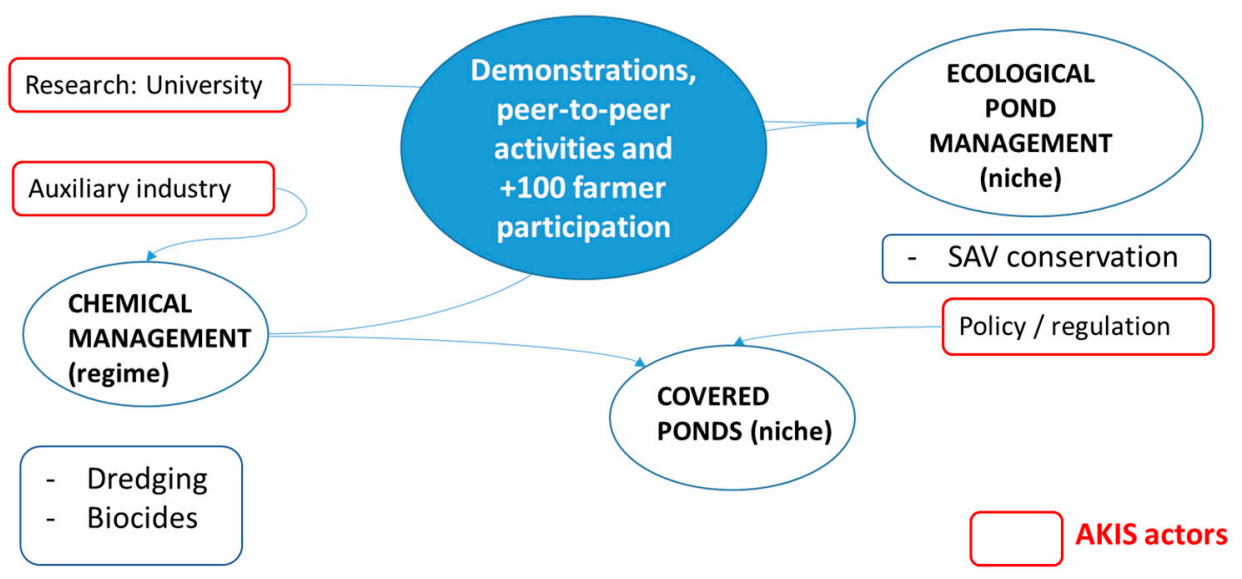

Figure 6. PONDs transition pathway (authors' elaboration).

However, there are some farmers who have already realised the benefits of maintaining aquatic biodiversity. They are aware that in their ponds the water quality values were better than those with biocide treatments or dredging. In addition, these farmers spent significant less money because they neither needed chemical treatments nor additional labour. Based on these experiences, it seems necessary to disseminate and demonstrate scientific results to farmers and other stakeholders, which could benefit both the greenhouse sector and the environment, and in doing so, reconnect farmers to nature.

\section{Conclusions}

During the last decade, sustainable strategies have been extensively studied and experimented on at the niche level, with the support of AKIS actors. These strategies and techniques are gradually being adopted by farmers and their cooperatives and produce 
organizations. Based on the wide-scale adoption of biocontrol, there has been a significant increase of farmers establishing auxiliary flora between their crops (e.g., flower strips and banker plants) and ecological infrastructures around their greenhouses (e.g., hedgerows, biodiversity islands, and even nest-boxes for bird and microbat species). These efforts, led by individual farmers, collectively foster the presence of spontaneously appearing arthropods and other animals that play a major role reinforcing biological pest control and other ecosystem services, while helping to preserve the natural habitats in the surrounding landscape. With far less pesticides currently being used, several species of arthropods can now be commonly observed inside and around greenhouses [156].

Moreover, soil health and water pond management have been key areas used to help farmers recognise the importance of biodiversity. Instead of using biocides, techniques, such as biosolarisation and biofumigation in combination with organic matter addition, help to preserve soil micro- and macrobiota, gradually restoring soil fertility. The conservation of SAV in ponds offer another profitable example in which biodiversity supports processes directly related with crop production and environmental quality. Altogether, the development of these four niches have also contributed to the rise of organic farming interest in greenhouse horticulture, which now occupies approximately $12 \%$ of the total production area in Almeria. Ultimately, the adoption of sustainable strategies and certifications (e.g., Demeter, Naturland, Bio Suisse) by farmers also favours the presence of autochthonous flora and fauna around greenhouses, transforming these anthropised landscapes and the people living and working on them more connected with nature.

From all four niche cases presented, we can conclude that the "connection to nature" of the majority of farmers in Almeria comes from an appreciation of the functionality (i.e., ecosystem services) that different biological elements (e.g., soil organisms, invertebrates, terrestrial and aquatic plants) provide for farm activity.

On-farm demonstrations have been the most influential tools used to support knowledge transfer to (and between) farmers, based (particularly) on the experiences drawn from three of the studied niches: biological control (e.g., IPMWorks, NEFERTITI), ecological restoration and soil health (e.g., experimental farm installations and demos, workshops and farm days, Best4Soil and NEFERTITI). In the majority of cases, farmers clearly understand the positive impacts that conserving and promoting biodiversity brings to their crops. In this regard, both research and innovation projects are useful to produce positive changes and to highlight the benefits of agricultural practices becoming more embedded in nature.

Based on the four niche case studies, and returning to Gliessman's five levels of agroecology, we consider that the greenhouse sector in Almeria is well advanced and continues experimentation at level 1 (increasing efficiencies of inputs), and is currently in level 2 (substitution of alternative practices and inputs) with the beginnings of a strong base for transition to level 3 (redesign of the whole agroecosystem based on ecological processes), aided by the reconnection with nature which is implicated in the transition from level 2 to level 3. In order to reach further levels, it is necessary to re-establish the communication between growers and consumers (level 4). Initiatives, such as Cute Solar (www.cutesolar.eu; accessed on 5 October 2021) or CO-FRESH (www.co-fresh.eu; accessed on 5 October 2021), are helping consumers and other stakeholders across Europe to visualise the process of how crops are grown in greenhouses by farmers, thus serving as a first step to enable a closer communication and ultimately a reconnection between both groups.

The multiple-level perspective has shed light on how transformations take place from one level to another. The analysis of local, multi-actor niche activity and experimentation has allowed us to consider the individual, collective and organizational behaviour of farmers, business, and related research and market institutions as well as policy actors. We have traced how niches or discreet experiments and projects have gone from isolated activities to dominate regime level patterns within the agri system. In some instances, we also demonstrated how the landscape or prevailing meta-narrative of HNC can be influenced, with farmers recognising ecosystem services as an integral part of their farming activity. The activation of resources and capabilities within the AKIS, along with co- 
creation, have been key factors in creating realisable and feasible paths and enabling sustainable transitions.

With respect to the roles of different types of AKIS actors, we can observe that research centres have provided a solid base in all four cases, but only IPM and biocontrol (and currently, to a lesser degree, ecosystem restoration and soil health) have received enough attention through dissemination/transfer activities to farmers to result in regime change and landscape influence. The auxiliary industry has also played an important role in IPM (but indirectly in ecological restoration) and soil health ("biostimulants"), but less so in ecosystem restoration and pond management niches. In this regard, water pond management is clearly the least developed area, but opportunities exist to broaden the adoption of this technique through the involvement of more AKIS actors and demonstrations. Public administrations have played an important role in promoting biocontrol, ecosystem restoration and soil health, but in the case of pond management, policies, such as subsidies for pond covers, have actually jeopardised the adoption of ecological pond management.

\section{Limitations and Further Research}

Further research is required to understand farmers' more profound appreciation of nature, not just the benefits, but the deep appreciation of living entities and the surrounding ecosystems in which their economic activities take place. Although these benefits (i.e., ecosystem services) are important, the farmers' knowledge and beliefs (i.e., cultural services) are determinants of whether they protect, ignore, neglect, or even destroy biodiversity [157]. In this regard, social scientists could work, documenting farmers' recognition of these cultural services. This research, together with the agroecological research carried out in greenhouses in the region, could be combined to create specific environmental education programs, to encourage farmers' appreciation of nature, and support biodiversity conservation.

We have illustrated that farmers' reconnection with nature has been mediated by on-farm practices. The main driver for adoption has generally either demonstrated benefits (farm demonstration or peer-to-peer learning) or external crises and "windows of opportunity" from landscape level influences. This implies that further research is needed on economic benefits and costs for adopting more sustainable practices that place farming within a recognition of nature, so as to encourage adoption by farmers. However, costbenefit analysis is often a result of scale, and if there is not widespread adoption, then a lack of scale remains an issue.

In particular, with respect to IPM, although the use of biological control agents is common among farmers, there is still some reliance on the use of pesticides, particularly against some pests for which no natural enemies are currently commercially available. Further research is necessary to identify predators and/or parasitoids of these pest species and revise and optimize the already existing IPM protocols with additional compatible tools (e.g., biological products). Moreover, with respect to ecological restoration of Almeria's greenhouse area, it is necessary to quantify natural pest control, which is found in semi natural habitats and to determine which species or functional traits are responsible to exert this biological control. This knowledge would optimize revegetation designs and their functionality for pest control. More importantly it would encourage a paradigm shift in the agricultural sector and society regarding the importance of conserving semi natural habitats and biodiversity in the agricultural landscape. Indicators of healthy, living soils are scarce but they are a key to facilitate the reconnection with nature by means of soil management. The visualisation of the soil as a natural system is not so obvious. Traditional methods, i.e., the incorporation of animal manure for building the 'arenado' system, persist in the mind of most of the growers in Almeria, who appreciate and identify the characteristics of a good soil, by means of the structure and content of organic matter. Overall, there is willingness to change, but further research would support this transition, particularly surveys identifying the connection of farmers with nature, by means of their knowledge and beliefs towards soil. The main limitation to continue the spread of knowledge among farmers on ecological 
pond management techniques involves the lack of dissemination of results by public or private entities, particularly on-farm demonstrations to and between farmers. AKIS actors can move the transition forward to a more sustainable model in the most practical sense, by demonstrations in situ, showing agronomic, environmental, and economic advantages, motivating more farmers to take the step towards an agroecological transition.

Finally, even though the four niches are interconnected, the strategies to improve sustainability are managed separately. Further research on designing and organising coupled innovations, including the reconnection of farmers with nature as part of the process, is needed [158].

Author Contributions: Conceptualisation, C.G., S.M. and E.C.-M.; methodology, C.G., S.M. and E.C.-M.; investigation, C.G., S.M., E.C.-M., M.d.C.-G., M.G., J.I.M.-G., E.R., J.v.d.B. and M.J.; writingoriginal draft preparation, C.G., S.M., E.C.-M., M.d.C.-G., M.G., J.I.M.-G., E.R., J.v.d.B. and M.J.; writing-review and editing, all authors; visualisation, C.G., S.M., E.C.-M., M.d.C.-G., M.G., J.I.M.-G., E.R., J.v.d.B. and M.J.; supervision, C.G. and E.C.-M.; project administration, C.G. and E.C.-M.; funding acquisition, C.G., E.C-M., M.d.C.-G., M.G., J.I.M.-G., E.R. and J.v.d.B. All authors have read and agreed to the published version of the manuscript.

Funding: This research was funded by the following projects: Networking European Farms to Enhance Cross Fertilisation and Innovation Uptake through Demonstration (NEFERTITI) H2020, 772705; CO-creating sustainable and competitive FRuits and vEgetableS' value cHains in Europe (CO-FRESH) H2020, 101000852; IPMWorks (an EU-wide farm network demonstrating and promoting cost-effective IPM strategies) H2020, 101000339; Boosting 4 BEST practices for SOIL health in Europe (BEST4SOIL) H2020 817696 Networking and dissemination of knowledge on soil health; Implementación de Desarrollos Ecológicos para una Agricultura Sostenible- Implementation of ecological developments for a sustainable agriculture (GOIDEAS) Spanish Rural Development Programme (2014-2020) 07434, co-funded European Union 20190020007434; Instituto Nacional de Investigación y Tecnología Agraria y Alimentaria RTA2015-00012-C02-01 INIA.

Data Availability Statement: Data sharing not applicable. No new data were created or analyzed in this study.

Conflicts of Interest: The authors declare no conflict of interest.

\section{References}

1. Melchior, I.C.; Newig, J. Governing transitions towards sustainable agriculture-Taking stock of an emerging field of research. Sustainability 2021, 13, 528. [CrossRef]

2. Crippa, M.; Solazzo, E.; Guizzardi, D.; Monforti-Ferrario, F.; Tubiello, F.N.; Leip, A. Food systems are responsible for a third of global anthropogenic GHG emissions. Nat. Food 2021, 2, 198-209. [CrossRef]

3. Rockström, J.; Edenhofer, O.; Gaertner, J.; DeClerck, F. Planet-proofing the global food system. Nat. Food 2020, 1, 3-5. [CrossRef]

4. Barrett, H.; Rose, D.C. Perceptions of the Fourth Agricultural Revolution: What's In, What's Out, and What Consequences are Anticipated? Sociol. Rural. 2020. [CrossRef]

5. Hebinck, A.; Klerkx, L.; Elzen, B.; Kok, K.P.W.; König, B.; Schiller, K.; Tschersich, J.; van Mierlo, B.; von Wirth, T. Beyond food for thought-Directing sustainability transitions research to address fundamental change in agri-food systems. Environ. Innov. Soc. Transit. 2021, 41, 81-85. [CrossRef]

6. Klerkx, L.; Begemann, S. Supporting food systems transformation: The what, why, who, where and how of mission-oriented agricultural innovation systems. Agric. Syst. 2020, 184, 102901. [CrossRef] [PubMed]

7. Zurek, M.; Hebinck, A.; Selomane, O. Looking across diverse food system futures: Implications for climate change and the environment. Q Open 2021, 1. [CrossRef]

8. UNEP. Making Peace with Nature: A Scientific Blueprint to Tackle the Climate, Biodiversity and Pollution Emergencies; UNEP: Nairobi, Kenia, 2021.

9. Sala, O.E.; Chapin, F.S., III; Armesto, J.J.; Berlow, E.; Bloomfield, J.; Dirzo, R.; Huber-Sanwald, E.; Huenneke, L.F.; Jackson, R.B.; Kinzig, A.; et al. Global Biodiversity Scenarios for the Year 2100. Science 2000, 287, 1770-1774. [CrossRef] [PubMed]

10. Díaz, S.; Settele, J.; Brondízio, E.S.; Ngo, H.T.; Agard, J.; Arneth, A.; Balvanera, P.; Brauman, K.A.; Butchart, S.H.M.; Chan, K.M.A.; et al. Pervasive human-driven decline of life on Earth points to the need for transformative change. Science 2019, 366. [CrossRef] [PubMed]

11. Desneux, N.; Decourtye, A.; Delpuech, J.-M. The Sublethal Effects of Pesticides on Beneficial Arthropods. Annu. Rev. Entomol. 2007, 52, 81-106. [CrossRef] [PubMed] 
12. Alavanja, M.C.R. Introduction: Pesticides Use and Exposure, Extensive Worldwide. Rev. Environ. Health 2009, $24,303-309$. [CrossRef]

13. Gomiero, T.; Pimentel, D.; Paoletti, M.G. Environmental Impact of Different Agricultural Management Practices: Conventional vs. Organic Agriculture. CRC Crit. Rev. Plant Sci. 2011, 30, 95-124. [CrossRef]

14. Vermunt, D.A.; Negro, S.O.; Van Laerhoven, F.S.J.; Verweij, P.A.; Hekkert, M.P. Sustainability transitions in the agri-food sector: How ecology affects transition dynamics. Environ. Innov. Soc. Transit. 2020, 36, 236-249. [CrossRef]

15. Mendoza-Fernández, A.J.; Martínez-Hernández, F.; Pérez-García, F.J.; Garrido-Becerra, J.A.; Benito, B.M.; Salmerón-Sánchez, E.; Guirado, J.; Merlo, M.E.; Mota, J.F. Extreme habitat loss in a Mediterranean habitat: Maytenus senegalensis subsp. europaea. Plant Biosyst.-Int. J. Deal. Asp. Plant Biol. 2015, 149, 503-511. [CrossRef]

16. Guterres, A. Secretary-General's Address at Columbia University: "The State of the Planet". Available online: https: //www.un.org/sg/en/content/sg/speeches/2020-12-02/address-columbia-university-the-state-of-the-planet (accessed on 3 December 2021).

17. Eurostat. Agriculture, Forestry and Fishery Statistics, 2020th ed.; Cook, E., Ed.; EU: Brussels, Belgium, 2020; ISBN 978-92-76-21522-6.

18. Deconinck, K. Concentration and Market Power in the Food Chain; OECD Publishing: Paris, France, 2021 ; Volume 151.

19. Dasgupta, P. The Economics of Biodiversity: The Dasgupta Review; HM Treasury: London, UK, 2021; ISBN 978-1-911680-29-1.

20. Dupeux, B. Beyond net zero emission in agriculture EEB pathway for a net-zero agriculture and agriculture-related land emission. Eur. Environ. Bur. 2021. Available online: chrome-extension://bocbaocobfecmglnmeaeppambideimao/pdf/viewer.html?file= https $\% 3 \mathrm{~A} \% 2 \mathrm{~F} \% 2 \mathrm{Feeb}$.org $\% 2$ Fwp-content $\% 2$ Fuploads $\% 2 \mathrm{~F} 2021 \% 2 \mathrm{~F} 07 \% 2 \mathrm{FEEB}$-pathways-for-a-net-zero-agriculture.pdf (accessed on 5 October 2021)

21. Poore, J.; Nemecek, T. Reducing food's environmental impacts through producers and consumers. Science 2018, 360, 987-992. [CrossRef] [PubMed]

22. Benton, T.; Bieg, C.; Harwatt, H.; Pudassaini, R.; Wellesley, L. Food System Impacts on Biodiversity Loss Three levers for Food; Chatham House: London, UK, 2021; ISBN 9783030023188.

23. FAO. Guiding the Transition to Sustainable Food and Agricultural Systems the 10 Elements of Agroecology; FAO: Rome, Italy, 2018.

24. Knierim, A.; Labarthe, P.; Laurent, C.; Prager, K.; Kania, J.; Madureira, L.; Ndah, T.H. Pluralism of agricultural advisory service providers-Facts and insights from Europe. J. Rural Stud. 2017, 55, 45-58. [CrossRef]

25. Pigford, A.A.E.; Hickey, G.M.; Klerkx, L. Beyond agricultural innovation systems? Exploring an agricultural innovation ecosystems approach for niche design and development in sustainability transitions. Agric. Syst. 2018, 164, 116-121. [CrossRef]

26. Köhler, J.; Geels, F.W.; Kern, F.; Markard, J.; Onsongo, E.; Wieczorek, A.; Alkemade, F.; Avelino, F.; Bergek, A.; Boons, F.; et al. An agenda for sustainability transitions research: State of the art and future directions. Environ. Innov. Soc. Transit. 2019, 31, 1-32. [CrossRef]

27. Geels, F.W. Socio-technical transitions to sustainability: A review of criticisms and elaborations of the Multi-Level Perspective. Curr. Opin. Environ. Sustain. 2019, 39, 187-201. [CrossRef]

28. Markard, J.; Raven, R.; Truffer, B. Sustainability transitions: An emerging field of research and its prospects. Res. Policy 2012, 41, 955-967. [CrossRef]

29. Aubert, B.A.; Schroeder, A.; Grimaudo, J. IT as enabler of sustainable farming: An empirical analysis of farmers' adoption decision of precision agriculture technology. Decis. Support Syst. 2012, 54, 510-520. [CrossRef]

30. El Bilali, H. Innovation-Sustainability Nexus in Agriculture Transition: Case of Agroecology. Open Agric. 2019, 4, 1-16. [CrossRef]

31. van Mierlo, B.; Beers, P.J. Understanding and governing learning in sustainability transitions: A review. Environ. Innov. Soc. Transit. 2020, 34, 255-269. [CrossRef]

32. Elzen, B.; Barbier, M.; Cerf, M.; Grin, J. Stimulating transitions towards sustainable farming systems. In Farming Systems Research into the 21st Century: The New Dynamic; Springer: Dordrecht, The Netherlands, 2012; pp. 431-455. [CrossRef]

33. Ingram, J. A food systems approach to researching food security and its interactions with global environmental change. Food Secur. 2011, 3, 417-431. [CrossRef]

34. Spaargaren, G.; Oosterveer, P.; Loeber, A. Sustainability Transitions in Food Consumption, Retail and Production. 2011. Available online: https: / / www.taylorfrancis.com/chapters/edit/10.4324/9780203135921-7/sustainability-transitions-food-consumptionretail-production-gert-spaargaren-peter-oosterveer-anne-loeber (accessed on 5 October 2021).

35. STRN. Sustainability Transitions: Policy and Practices; Publications Office of the European Union: Luxembourg, 2019; ISBN 978-92-9480-086-2.

36. Geels, F.W. Technological transitions as evolutionary reconfiguration processes: A multi-level perspective and a case-study. Res. Policy 2002, 31, 1257-1274. [CrossRef]

37. Smith, A.; Voß, J.-P.; Grin, J. Innovation studies and sustainability transitions: The allure of the multi-level perspective and its challenges. Res. Policy 2010, 39, 435-448. [CrossRef]

38. Rip, A.; Kemp, R. Technological Change; Rayner, S., Malone, E.L., Eds.; Battelle Press: Columbus, OH, USA, 1998; Volume II.

39. Geels, F.W. The multi-level perspective on sustainability transitions: Responses to seven criticisms. Environ. Innov. Soc. Transit. 2011, 1, 24-40. [CrossRef]

40. Geels, F.W. Processes and patterns in transitions and system innovations: Refining the co-evolutionary multi-level perspective. Technol. Forecast. Soc. Chang. 2005, 72, 681-696. [CrossRef] 
41. El Bilali, H. Research on agro-food sustainability transitions: Where are food security and nutrition? Food Secur. 2019, 11, 559-577. [CrossRef]

42. Wigboldus, S.; Klerkx, L.; Leeuwis, C.; Schut, M.; Muilerman, S.; Jochemsen, H. Systemic perspectives on scaling agricultural innovations: A review. Agron. Sustain. Dev. 2016, 36, 46. [CrossRef]

43. El Bilali, H. Transition Heuristic Frameworks in Research on Agro-Food Sustainability Transitions. Environ. Dev. Sustain. 2020, 22, 1693-1728. [CrossRef]

44. Gaitán-Cremaschi, D.; Klerkx, L.; Duncan, J.; Trienekens, J.H.; Huenchuleo, C.; Dogliotti, S.; Contesse, M.E.; Benitez-Altuna, F.J.; Rossing, W.A.H. Sustainability transition pathways through ecological intensification: An assessment of vegetable food systems in Chile. Int. J. Agric. Sustain. 2020, 18, 131-150. [CrossRef]

45. Weber, H.; Poeggel, K.; Eakin, H.; Fischer, D.; Lang, D.J.; Von Wehrden, H.; Wiek, A. What are the ingredients for food systems change towards sustainability?-Insights from the literature. Environ. Res. Lett. 2020, 15. [CrossRef]

46. Soga, M.; Gaston, K.J. Extinction of experience: The loss of human-nature interactions. Front. Ecol. Environ. 2016, 14, 94-101. [CrossRef]

47. Bratman, G.N.; Daily, G.C.; Levy, B.J.; Gross, J.J. The benefits of nature experience: Improved affect and cognition. Landsc. Urban Plan. 2015, 138, 41-50. [CrossRef]

48. Gosling, E.; Williams, K.J.H. Connectedness to nature, place attachment and conservation behaviour: Testing connectedness theory among farmers. J. Environ. Psychol. 2010, 30, 298-304. [CrossRef]

49. Geng, L.; Xu, J.; Ye, L.; Zhou, W.; Zhou, K. Connections with Nature and Environmental Behaviors. PLoS ONE 2015, 10, e0127247. [CrossRef]

50. Schultz, W.P. The structure of environmental concern: Concern for self, other people, and the biosphere. J. Environ. Psychol. 2001, 21,327-339. [CrossRef]

51. European Commission. Farm to Fork Strategy: For a Fair, Healthy and Environmentally-Friendly Food System. Available online: https: / / ec.europa.eu/food/horizontal-topics/farm-fork-strategy_en (accessed on 30 September 2021).

52. FAO; UNEP. The FAO-UNEP Sustainable Food Systems Programme. Available online: http://www.fao.org/fileadmin/templates/ ags/docs/SFCP/Flyer_SP_01.pdf (accessed on 21 October 2021).

53. Gliessman, S. Transforming food systems with agroecology. Agroecol. Sustain. Food Syst. 2016, 40, 187-189. [CrossRef]

54. Guerrero, M.M.; Guirao, P.; Martinez-Lluch, M.C.; Tello, J.C.; Lacasa, A. Soil fatigue and its specificity towards pepper plants in greenhouses. Span. J. Agric. Res. 2014, 12, 644-652. [CrossRef]

55. Roditakis, E.; Vasakis, E.; García-Vidal, L.; del Rosario Martínez-Aguirre, M.; Rison, J.L.; Haxaire-Lutun, M.O.; Nauen, R.; Tsagkarakou, A.; Bielza, P. A four-year survey on insecticide resistance and likelihood of chemical control failure for tomato leaf miner Tuta absoluta in the European/Asian region. J. Pest Sci. 2018, 91, 421-435. [CrossRef]

56. AKIS. Preparing for Future AKIS in Europe; AKIS: Brussels, Belgium, 2019.

57. United Nations. 17 Sustainable Development Goals (SDGs). Available online: https://sdgs.un.org/goals (accessed on 1 September 2021).

58. Pereira, L.M.; Bennett, E.; Biggs, R.; Peterson, G.; McPhearson, T.; Norström, A.; Olsson, P.; Preiser, R.; Raudsepp-Hearne, C.; Vervoort, J. Seeds of the Future in the Present: Exploring Pathways for Navigating Towards "Good" Anthropocenes. In Urban Planet: Knowledge towards Sustainable Cities; Elmqvist, T., Bai, X., Frantzeskaki, N., Griffith, C., Maddox, D., McPhearson, T., Parnell, S., Romero-Lankao, P., Simon, D., Watkins, M., Eds.; Cambridge University Press: Cambridge, UK, 2018 ; pp. 327-350. ISBN 9781316647554.

59. Joffre, O.M.; Klerkx, L.; Khoa, T.N.D. Aquaculture innovation system analysis of transition to sustainable intensification in shrimp farming. Agron. Sustain. Dev. 2018, 38. [CrossRef]

60. Klerkx, L.; van Mierlo, B.; Leeuwis, C. Evolution of systems approaches to agricultural innovation: Concepts, analysis and interventions. In Farming Systems Research into the 21st Century: The New Dynamic; Springer: Dordrecht, The Netherlands, 2012; pp. 457-483. [CrossRef]

61. Turner, J.A.; Klerkx, L.; White, T.; Nelson, T.; Everett-Hincks, J.; Mackay, A.; Botha, N. Unpacking systemic innovation capacity as strategic ambidexterity: How projects dynamically configure capabilities for agricultural innovation. Land Use Policy 2017, 68, 503-523. [CrossRef]

62. Geels, F.W.; Kemp, R. Dynamics in socio-technical systems: Typology of change processes and contrasting case studies. Technol. Soc. 2007, 29, 441-455. [CrossRef]

63. Giagnocavo, C.; Aguilera, D.U. The case for proactive cooperative banks and local development: Innovation, growth, and community building in Almeria, Spain. In Financial Cooperatives and Local Development; Goglio, S., Alexopoulos, Y., Eds.; Routledge: New York, NY, USA, 2013; pp. 93-110.

64. Giagnocavo, C.; Fernández-Revuelta Pérez, L.; Uclés Aguilera, D. Modern agriculture, sustainable innovation and cooperative banks: The development of Almería (1963-2010). In Proceedings of the Financial Cooperative Approaches to Local Development through Sustainable Innovation, Trento, Italy, 10-11 June 2010; pp. 10-11.

65. Giagnocavo, C. The Development of the Cooperative Movement and Civil Society in Almeria, Spain: Something from Nothing? Sustainability 2020, 12, 9820. [CrossRef]

66. Giagnocavo, C.; Galdeano-Gómez, E.; Pérez-Mesa, J. Cooperative Longevity and Sustainable Development in a Family Farming System. Sustainability 2018, 10, 2198. [CrossRef] 
67. Angel Aznar-Sanchez, J.; Sanchez-Picon, A. Innovation and District around a "Miracle": Configuration of the local productive system in intensive agriculture in Almeria. Rev. Hist. Ind. 2010, 42, 157-193.

68. COEXPHAL. COEXPHAL Annual Report 2020-21; COEXPHAL: Almería, Spain, 2021.

69. Castro, A.J.; López-Rodríguez, M.D.; Giagnocavo, C.; Gimenez, M.; Céspedes, L.; La Calle, A.; Gallardo, M.; Pumares, P.; Cabello, J.; Rodríguez, E.; et al. Six Collective Challenges for Sustainability of Almería Greenhouse Horticulture. Int. J. Environ. Res. Public Health 2019, 16, 4097. [CrossRef]

70. Dudley, N.; Alexander, S. Agriculture and biodiversity: A review. Biodiversity 2017, 18, 45-49. [CrossRef]

71. Sánchez-Bayo, F.; Wyckhuys, K.A.G. Worldwide decline of the entomofauna: A review of its drivers. Biol. Conserv. 2019, 232, 8-27. [CrossRef]

72. Lundgren, J.G.; Fausti, S.W. Trading biodiversity for pest problems. Sci. Adv. 2015, 1, e1500558. [CrossRef]

73. Costanza, R.; D'Arge, R.; de Groot, R.; Farber, S.; Grasso, M.; Hannon, B.; Limburg, K.; Naeem, S.; O’Neill, R.V.; Paruelo, J.; et al The value of the world's ecosystem services and natural capital. Ecol. Econ. 1998, 25, 3-15. [CrossRef]

74. Egea, F.J.; Torrente, R.G.; Aguilar, A. An efficient agro-industrial complex in Almería (Spain): Towards an integrated and sustainable bioeconomy model. N. Biotechnol. 2018, 40, 103-112. [CrossRef]

75. Cajamar. Análisis de la campaña hortofrutícola de Almería. Campaña 2019/2020. Available online: https:/ /www.cajamar. es/es/agroalimentario/innovacion/formacion/actividades-de-transferencia/ano-2020/webinar-analisis-de-la-campanahortofruticola-campana-20192020/ (accessed on 5 October 2021).

76. Francis, C.; Lieblein, G.; Gliessman, S.; Breland, T.A.; Creamer, N.; Harwood, R.; Salomonsson, L.; Helenius, J.; Rickerl, D.; Salvador, R.; et al. Agroecology: The Ecology of Food Systems. J. Sustain. Agric. 2003, 22, 99-118. [CrossRef]

77. Gliessman, S.R. Agroecology: The Ecology of Sustainable Food Systems, 2nd ed.; CRC Press: Boca Raton, FL, USA, 2007.

78. Paulitz, T.C.; Richard, R.B. Biological control in greenhouse systems. Annu. Rev. Phytopathol. 2001, 39, 101-133. [CrossRef] [PubMed]

79. Messelink, G.J.; Labbé, R.; Marchand, G.; Tavella, L. Sweet Peppers. In Integrated Pest and Disease Management in Greenhouse Crops, Springer International Publishing: Cham, Switzerland, 2020; Volume 22, pp. 513-535.

80. Espinosa, P.J.; Bielza, P.; Contreras, J.; Lacasa, A. Insecticide resistance in field populations of Frankliniella occidentalis (Pergande) in Murcia (south-east Spain). Pest Manag. Sci. 2002, 58, 967-971. [CrossRef] [PubMed]

81. Glass, R. Biological Control in the Greenhouses of Almería and Challenges for a Sustainable Intensive Production. Outlooks Pest Manag. 2012, 23, 276-279. [CrossRef]

82. van Lenteren, J.C. Success in Biological Control of Arthropods by Augmentation of Natural Enemies Inundative release Seasonal inoculative release. In Biological Control: Measures of Success; Springer: Dordrecht, The Netherlands, 2000; pp. 77-103.

83. Mota, J.F.; Peñas, J.; Castro, H.; Cabello, J.; Guirado, J.S. Agricultural development vs biodiversity conservation: The Mediterranean semiarid vegetation in El Ejido (Almeria, southeastern Spain). Biodivers. Conserv. 1996, 5, 1597-1617. [CrossRef]

84. Mendoza-Fernández, A.J.; Martínez-Hernández, F.; Salmerón-Sánchez, E.; Pérez-García, F.J.; Teruel, B.; Merlo, M.E.; Mota, J.F. The relict ecosystem of maytenus senegalensis subsp. europaea in an agricultural landscape: Past, present and future scenarios. Land 2021, 10, 1. [CrossRef]

85. Losey, J.; Vaughan, M. The Economic Value of Ecological Services Provided by Insects. Bioscience 2006, 56, 311-323. [CrossRef]

86. Junta De Andalucia Consejeria de Agricultura, Ganaderia, Pesca y Desarrollo Rural. Agencia de Gestión Agraria y Pesquera de Andalucía. Available online: https://www.cap.junta-andalucia.es/agriculturaypesca/observatorio/servlet/FrontController? action $=$ RecordContent\&table $=11031 \&$ element $=1586184 \&$ (accessed on 3 December 2021).

87. Garcia-Garcia, M.C.; Céspedes, A.J.; Lorenzo, P. El Sistema de Producción Hortícola Protegido de la Provincia de Almería; Consejeria de Agricultura, Ganaderia, Pesca y Desarrollo Rural de Andalucía: Sevilla, Spain, 2016; 180p.

88. Valera, D.L.; Belmonte, L.J.; Molina, F.D.; Lopez, A. Greenhouse Agriculture in Almería: A Comprehensive Techno-Economic Analysis; Cajamar Caja Rural: Almería, Spain, 2016; 408p.

89. Bouhot, D. La fatigue des sols. Position du probléme et principe du diagnostic. In La fatigue des sols. Diagnostic de la Fertilité dans le Systémes Culturaux; Institut National de la Recherche Agronomique (INRA): Paris, France, 1983; pp. 9-21.

90. Duque-Acevedo, M.; Belmonte-Ureña, L.J.; Plaza-Úbeda, J.A.; Camacho-Ferre, F. The Management of Agricultural Waste Biomass in the Framework of Circular Economy and Bioeconomy: An Opportunity for Greenhouse Agriculture in Southeast Spain. Agronomy 2020, 10, 489. [CrossRef]

91. Castillo-Díaz, F.J.; Marín-Guirao, J.I.; Belmonte-Ureña, L.J.; Tello-Marquina, J.C. Effect of Repeated Plant Debris Reutilization as Organic Amendment on Greenhouse Soil Fertility. Int. J. Environ. Res. Public Health 2021, 18, 11544. [CrossRef]

92. García-Raya, P.; Ruiz-Olmos, C.; Marín-Guirao, J.; Asensio-Grima, C.; Tello-Marquina, J.; de Cara-García, M. Greenhouse Soil Biosolarization with Tomato Plant Debris as a Unique Fertilizer for Tomato Crops. Int. J. Environ. Res. Public Health 2019, 16, 279. [CrossRef]

93. Gómez-Tenorio, M.A.; Lupión-Rodríguez, B.; Boix-Ruiz, A.; Ruiz-Olmos, C.; Marín-Guirao, J.I.; Tello-Marquina, J.C.; Camacho-Ferre, F.; de Cara-García, M. Meloidogyne -infested tomato crop residues are a suitable material for biodisinfestation to manage Meloidogyne sp. in greenhouses in Almería (south-east Spain). Acta Hortic. 2018, 1207, 217-222. [CrossRef]

94. Marín-Guirao, J.I.; Tello, J.C.; Díaz, M.; Boix, A.; Ruiz, C.A.; Camacho, F. Effect of greenhouse soil bio-disinfection on soil nitrate content and tomato fruit yield and quality. Soil Res. 2016, 54, 200-206. [CrossRef]

95. Torres, J.M. Uso agronómico de restos de cosecha en los invernaderos enarenados de la cuenca mediterranea. Fund. Cajamar 2016 
96. Connor, R. The United Nations World Water Development Report 2015: Water for a Sustainable World; UNESCO Publishing: Paris, France, 2015; Volume 1.

97. Caparrós-Martínez, J.; Rueda-Lópe, N.; Milán-García, J.; de Pablo Valenciano, J. Public policies for sustainability and water security: The case of Almeria (Spain). Glob. Ecol. Conserv. 2020, 23, e01037. [CrossRef]

98. Casas, J.; Toja, J.; Bonachela, S.; Fuentes, F.; Gallego, I.; Juan, M.; León, D.; Peñalver, P.; Pérez, C.; Sánchez, P. Artificial ponds in a Mediterranean region (Andalusia, southern Spain): Agricultural and environmental issues. Water Environ. J. 2011, 25, 308-317. [CrossRef]

99. Ayers, R.S.; Westcot, D.W. Water Quality for Agriculture; FAO Irrigation: Rome, Italy, 1985.

100. Nakayama, F.S.; Bucks, D.A. Water quality in drip/trickle irrigation: A review. Irrig. Sci. 1991, 12. [CrossRef]

101. Vergara, C.H.; Fonseca-Buendía, P. Pollination of Greenhouse Tomatoes by the Mexican bumblebee Bombus ephippiatus (Hymenoptera: Apidae). J. Pollinat. Ecol. 2012, 7, 27-30. [CrossRef]

102. van Ravestijn, W.; van der Sande, J. Use of bumblebees for the pollination of glasshouse tomatoes. Acta Hortic. 1991, 288, 204-212. [CrossRef]

103. Velthuis, H.H.W.; van Doorn, A. A century of advances in bumblebee domestication and the economic and environmental aspects of its commercialization for pollination. Apidologie 2006, 37, 421-451. [CrossRef]

104. Navarro Castillo, J.A. Introducción de abejorros como polinizadores en cultivos protegidos de Almería. Boletín Inst. Estud. Almer 1994, 101-118.

105. Van der Blom, J. La introducción artificial de la fauna auxiliar en cultivos agrícolas. Boletín Sanid. Veg. Plagas 2002, 28 , 107-118.

106. van der Blom, J.; Robledo, A.; Torres, S.; Sánchez, J.A. Consequences of the wide scale implementation of biological control in greenhouse horticulture in Almeria, Spain. Biol. Control 2009, 11, 8.

107. Marletto, F.; Patetta, A.; Manino, A. Laboratory assessment of pesticide toxicity to bumblebees. Bull. Insectol. 2003, 56, 155-158.

108. Parrón, T.; Hernández, A.; Pla, A.; Villanueva, E. Clinical and biochemical changes in greenhouse sprayers chronically exposed to pesticides. Hum. Exp. Toxicol. 1996, 15, 957-963. [CrossRef]

109. Beck, N.G.; Martin, N.A.; Workman, P.J. IPM for greenhouse crops in New Zealand: Grower acceptance. WPRS Bull. 1993, 16, 1.

110. Rodríguez, M.D.; Belda, J.E. Trips en los Cultivos Hortícolas Protegidos. Consejeria de Agricultura y Pesca; Junta de Andalucía: Sevilla, Spain, 1989; ISBN 978-84-505-8381-6.

111. Cabello, T.; Pascual, F.; Abad, M.M. Capturas de Frankliniella occidentalis (Pergande) (Thys.: Thripidae) en trampas de distintos colores en cultivos en invernaderos. Boletín Sanid. Veg. Plagas 1990, 17, 265-270.

112. Espinosa, P.J.; Bielza, P.; Contreras, J.; Lacasa, A. Field and laboratory selection of Frankliniella occidentalis (Pergande) for resistance to insecticides. Pest Manag. Sci. 2002, 58, 920-927. [CrossRef] [PubMed]

113. Calvo, F.J.; Bolckmans, K.; Belda, J.E. Biological control-based IPM in sweet pepper greenhouses using Amblyseius swirskii (Acari: Phytoseiidae). Biocontrol Sci. Technol. 2012, 22, 1398-1416. [CrossRef]

114. Vila, E.; Cabello, T. Biosystems engineering applied to greenhouse pest control. In Biosystems Engineering: Biofactories for Food Production in the Century XXI 2014; pp. 99-128. Available online: https://www.researchgate.net/publication/292356356 Biosystems_Engineering_Biofactories_for_Food_Production_in_the_Century_XXI (accessed on 5 October 2021).

115. Rincón-Amat, S. Possible Changes in Order to Solve the Pesticides Problem; Swedish University of Agricultural Sciences: Uppsala, Sweden, 2007.

116. Rodríguez, M.D.; Moreno, R.; Rodríguez, M.P.; Mirasol, E.; Lastres, J.M.; Téllez, M.M. IPM Tomate. In Programa de Manejo Integrado en el Cultivo del Tomate Bajo Plástico en Almeria; Junta de Andalucía: Sevilla, Spain, 1993; ISBN 84-87564-91-7.

117. Moreno Vázquez, R.E. Sanidad Vegetal en la Horticultura Protegida; Junta de Andalucía: Sevilla, Spain, 1994; p. 440. Available online: https:/ / www.researchgate.net/profile/Tomas-Cabello/publication/256445529_Noctuidos_Lep_Noctuidae_plagas_ en_cultivos_horticolas_en_invernaderos/links/54e3886c0cf2b2314f5d4492/Noctuidos-Lep-Noctuidae-plagas-en-cultivoshorticolas-en-invernaderos.pdf (accessed on 17 January 2022).

118. Giménez-Moolhuyzen, M.; van der Blom, J.; Lorenzo-Mínguez, P.; Cabello, T.; Crisol-Martínez, E. Photosynthesis inhibiting effects of pesticides on sweet pepper leaves. Insects 2020, 11, 69. [CrossRef]

119. Cabello, T.; Gámez, M.; Varga, Z.; Garay, J.; Carreño, R.; Gallego, J.R.; Fernández, F.J. Selection of Trichogramma spp. (Hym.: Trichogrammatidae) for the biological control of Tuta absoluta (Lep.: Gelechiidae) in greenhouses by an entomo-ecological simulation model. Integr. Control Prot. Crop. Mediterr. Clim. IOBC-WPRS Bull. 2012, 80, 171-176.

120. Gurr, G.M.; Wratten, S.D.; Luna, J.M. Multi-function agricultural biodiversity: Pest management and other benefits. Basic Appl. Ecol. 2003, 4, 107-116. [CrossRef]

121. Gilbertson, R.L.; Batuman, O.; Webster, C.G.; Adkins, S. Role of the Insect Supervectors Bemisia tabaci and Frankliniella occidentalis in the Emergence and Global Spread of Plant Viruses. Annu. Rev. Virol. 2015, 2, 67-93. [CrossRef] [PubMed]

122. Rodríguez, E.; van der Blom, J.; González, M.; Sánchez, E.; Janssen, D.; Ruiz, L.; Elorrieta, M.-A. Plant viruses and native vegetation in Mediterranean greenhouse areas. Sci. Hortic. 2014, 165, 171-174. [CrossRef]

123. Rodríguez, E.; González, M.; Paredes, D.; Campos, M.; Benítez, E. Selecting native perennial plants for ecological intensification in Mediterranean greenhouse horticulture. Bull. Entomol. Res. 2018, 108, 694-704. [CrossRef]

124. Cotes, B.; González, M.; Benítez, E.; De Mas, E.; Clemente-Orta, G.; Campos, M.; Rodríguez, E. Spider Communities and Biological Control in Native Habitats Surrounding Greenhouses. Insects 2018, 9, 33. [CrossRef] 
125. Rodríguez, E.; Schwarzer, V.; van der Blom, J.; Cabello, T.; González, M. The selection of native insectary plants for landscaping in greenhouse areas of SE Spain. IOBC/WPRS Bull. 2012, 75, 73-76.

126. Benítez, E.; Moreno, B.; Paredes, D.; González, M.; Campos, M.; Rodríguez, E. Ecological Infrastructures among greenhouses: Revegetation and soil quality. Ecosistemas 2019, 28, 54-62. [CrossRef]

127. Benítez, E.; Paredes, D.; Rodríguez, E.; Aldana, D.; González, M.; Nogales, R.; Campos, M.; Moreno, B. Bottom-up effects on herbivore-induced plant defences: A case study based on compositional patterns of rhizosphere microbial communities. Sci. Rep. 2017, 7, 6251. [CrossRef] [PubMed]

128. FAO. Addressing the Impacts of COVID-19 in Food Crises. April-December 2020: FAO's Component of the Global COVID-19 Humanitarian Response Plan; FAO: Rome, Italy, 2020.

129. Marín-Guirao, J.I.; De Cara-García, M.; Crisol-Martínez, E.; Gómez-Tenorio, M.Á.; García-Raya, P.; Tello-Marquina, J.C. Association of plant development to organic matter and fungal presence in soils of horticultural crops. Ann. Appl. Biol. 2019, 174, 339-348. [CrossRef]

130. Pankhurst, C.E.; Lynch, J.M. 12 The role of soil microbiology in sustainable intensive agriculture. Adv. Plant Pathol. 1995, 11, 229-247.

131. Norris, C.E.; Congreves, K.A. Alternative Management Practices Improve Soil Health Indices in Intensive Vegetable Cropping Systems: A Review. Front. Environ. Sci. 2018, 6. [CrossRef]

132. Gómez, A.J.C.L.; García, M.C.G.; Pérez-Parra, J.J.; Cuadrado, I.M. Caracterización de la Explotación Hortícola Protegida de Almería; Fundación para la Investigación Agraria en la Provincia de Almería (FIAPA); Fundación Cajamar: Almería, Spain, 2009; ISBN 84-88246-32-5.

133. de Cara, M. Mini-Paper: Anaerobic Soil Disinfestation and other Techniques of Non Chemical Soil Disinfestation Techniques. Available online: http://ec.europa.eu/eip/agriculture/sites/default/files/5_eip_sbd_mp_asd_final.pdf (accessed on 3 December 2021).

134. EIP-AGRI Focus Group on Soil-Borne Diseases: Final Report. Available online: https://ec.europa.eu/eip/agriculture/ sites/default/files/eip-agri_focus_group_on_ipm_practices_for_soil-borne_diseases_final_report_2015.pdf (accessed on 8 December 2021).

135. Junta De Andalucia Producción Ecológica en Andalucía Balance 2020. Available online: https://www.juntadeandalucia.es/ export/drupaljda/DECO21_Balance_Estadistico_Produccion_Ecologica_2020_v1.pdf (accessed on 13 December 2021).

136. Larkin, R.P. Effects of Selected Soil Amendments and Mulch Type on Soil Properties and Productivity in Organic Vegetable Production. Agronomy 2020, 10, 795. [CrossRef]

137. Marín-Guirao, J.I.; Hernández-Medina, J.A.; Martín-Expósito, E.; García-García, M.C.; de Cara-García, M. Efecto de tres tipos de acolchado en el suelo y el cultivo de tomate ecológico (Solanum lycopersicum L.) en invernadero. In Proceedings of the XXVIII Jornadas Tecnicas S.E.A.E., Online, 28-29 October 2020; ISBN 978-84-949844-2-6.

138. Bretones, F. El enarenado. In: Técnicas de producción en cultivos protegidos (Coord.: F. Camacho Ferre). Ed. Caja Rural Intermediterránea Cajamar Inst. Estud. Cajamar. 2003, I, 109-118.

139. Diacono, M.; Montemurro, F. Long-term effects of organic amendments on soil fertility. A review. Agron. Sustain. Dev. 2010, 30, 401-422. [CrossRef]

140. Gamliel, A.; van Bruggen, A.H.C. Maintaining soil health for crop production in organic greenhouses. Sci. Hortic. 2016, 208, 120-130. [CrossRef]

141. Contreras, J.I.; Baeza, R.; Segura, M. Cuantificación de los nutrientes aportados al suelo por la incorporación de los restos de los cultivos hortícolas de invernadero. In Proceedings of the XI Congreso SEAE, Vitoria-Gasteiz, Spain, 1-4 October 2014.

142. Salinas, J.; Meca, D.; del Moral, F. Short-Term Effects of Changing Soil Management Practices on Soil Quality Indicators and Crop Yields in Greenhouses. Agronomy 2020, 10, 582. [CrossRef]

143. Gómez-Tenorio, M.A.; Ruiz-Olmos, C.A.; Marín-Guirao, J.I.; Martín, F.; Camacho-Ferre, F.; Tello-Marquina, J.C. La biodesinfección de un suelo arenado y relación con el lixiviado de nitratos. In Actas de Horticultura; Sociedad Española de Ciencias Hortícolas: Córdoba, Spain, 2015; pp. 16-21. ISBN 978-84-606-8547-0.

144. Martín-Expósito, E.; Marín-Guirao, J.I.; Hernández-Medina, J.A.; García-García, M.C.; de Cara-García, M. ¿Es suficiente un único abonado de fondo con estiércol en un cultivo de tomate ecológico bajo invernadero? In Proceedings of the VIII Congreso Internacional Agroecología, Vigo, Spain, 1-3 July 2020; pp. 685-686, ISBN 978-84-09-21743-4.

145. Marín-Guirao, J.I.; Tello-Marquina, J.C. Microbiota edáfica y fatiga de suelo en invernaderos de la provincia de Granada. In I Jornadas de Transferencia Hortofrutícola de CIAMBITAL; Camacho-Ferre, F., Valera-Martínez, D.L., Belmonte-Ureña, L., Herrero-Sánchez, C., Reca-Cardeña, J., Marín-Membrive, P., del Pino-Gracia, A., Casa-Fernández, M., Eds.; Universidad de Almeria, CIAMBITAL: Almeria, Spain, 2017; pp. 17-36. ISBN 978-84-16389-98-8.

146. Marín-Guirao, J.I.; de Cara, M.; Tello-Marquina, J.C. Effect of soil biodisinfection on soil fungal communities associated to horticultural crops. Ecosistemas 2019, 28, 63-72. [CrossRef]

147. Marín-Guirao, J.; Gómez-Tenorio, M.A.; Castillo -Díaz, F.J.; Magdaleno-González, J.; Tello-Marquina, J.C. Incidencia de la biodesinfección de suelos de invernadero usando restos vegetales del cultivo de pimiento sobre la microbiota edáfica (hongos y bacterias). In Proceedings of the Congreso Internacional de Sistemas Agrarios Tradicionales, V Encuentro InterVegas, La Laguna, Tenerife, Spain, 24-26 October 2019; pp. 23-26. 
148. Marín-Guirao, J.I.; Martín-Expósito, E.; Hernández-Medina, J.A.; García-García, M.C.; de Cara-García, M. Incidencia de la biosolarización en suelo desnudo y arenado sobre la microbiota edáfica. In Proceedings of the VIII Congreso Internacional Agroecología, Online, 2-3 July 2020; Simón, X., Pérez-Neira, D., Copena, D., Eds.; pp. 683-684.

149. BOJA, Orden del 6 de abril. Boletín Of. Junta Andal. 2017, 69, 96-118. Available online: https://www.juntadeandalucia.es/boja/ 2017/66/index.html (accessed on 17 January 2022).

150. MAPA. Lista Comunitaria de Sustancias Activas Aprobadas, Excluidas y en Evaluación Comunitaria, Sustancias de Bajo Riesgo, Sustancias Candidatas a la Sustitución y Lista de Sustancias Básicas. Available online: https://www.mapa.gob.es/agricultura/ pags/fitos/registro/fichas/pdf/Lista_Sustancias_activas_aceptadas_excluidas.pdf (accessed on 3 December 2021).

151. Juan, M.; Casas, J.; Bonachela, S.; Fuentes-Rodríguez, F.; Gallego, I.; Elorrieta, M.A. Construction characteristics and management practices of in-farm irrigation ponds in intensive agricultural systems-Agronomic and Environmental Implications. Irrig. Drain. 2012, 61, 657-665. [CrossRef]

152. Bonachela, S.; Juan, M.; Casas, J.J.; Fuentes-Rodríguez, F.; Gallego, I.; Elorrieta, M.A. Pond management and water quality for drip irrigation in Mediterranean intensive horticultural systems. Irrig. Sci. 2013, 31, 769-780. [CrossRef]

153. Scheffer, M. The story of some shallow lakes. In Ecology of Shallow Lakes; Population and Community Biology Series; Springer: Dordrecht, The Netherlands, 2004; Volume 22.

154. Casas, J.; Sánchez-Oliver, S.J.; Sanz, A.; Furné, M.; Trenzado, C.; Juan, M.; Paracuellos, M.; Suárez, M.D.; Fuentes, F.; Gallego, I.; et al. The paradox of the conservation of an endangered fish species in a Mediterranean region under agricultural intensification. Biol. Conserv. 2011, 144, 253-262. [CrossRef]

155. Casas, J.J.; Toja, J.; Peñalver, P.; Juan, M.; León, D.; Fuentes-Rodríguez, F.; Gallego, I.; Fenoy, E.; Pérez-Martínez, C.; Sánchez, P.; et al. Farm Ponds as Potential Complementary Habitats to Natural Wetlands in a Mediterranean Region. Wetlands 2012, 32, 161-174. [CrossRef]

156. Robledo, A.; Pekas, A. Guía de Campo de los Artrópodos de los Invernaderos Hortícolas; Phytoma-España: Valencia, Spain, 2020.

157. Horgan, F.G.; Mundaca, E.A.; Crisol-Martínez, E. Emerging Patterns in Cultural Ecosystem Services as Incentives and Obstacles for Raptor Conservation. Birds 2021, 2, 185-206. [CrossRef]

158. Meynard, J.-M.; Jeuffroy, M.-H.; Le Bail, M.; Lefèvre, A.; Magrini, M.-B.; Michon, C. Designing coupled innovations for the sustainability transition of agrifood systems. Agric. Syst. 2017, 157, 330-339. [CrossRef] 